\title{
The Lagrangian chemistry and transport model ATLAS: simulation and validation of stratospheric chemistry and ozone loss in the winter 1999/2000
}

\author{
I. Wohltmann, R. Lehmann, and M. Rex \\ Alfred Wegener Institute for Polar and Marine Research, Potsdam, Germany \\ Received: 11 May 2010 - Published in Geosci. Model Dev. Discuss.: 1 June 2010 \\ Revised: 28 September 2010 - Accepted: 21 October 2010 - Published: 1 November 2010
}

\begin{abstract}
ATLAS is a new global Lagrangian Chemistry and Transport Model (CTM), which includes a stratospheric chemistry scheme with 46 active species, 171 reactions, heterogeneous chemistry on polar stratospheric clouds and a Lagrangian denitrification module. Lagrangian (trajectorybased) models have several important advantages over conventional Eulerian models, including the absence of spurious numerical diffusion, efficient code parallelization and no limitation of the largest time step by the Courant-FriedrichsLewy criterion. This work describes and validates the stratospheric chemistry scheme of the model. Stratospheric chemistry is simulated with ATLAS for the Arctic winter 1999/2000, with a focus on polar ozone depletion and denitrification. The simulations are used to validate the chemistry module in comparison with measurements of the SOLVE/THESEO 2000 campaign. A Lagrangian denitrification module, which is based on the simulation of the nucleation, sedimentation and growth of a large number of polar stratospheric cloud particles, is used to model the substantial denitrification that occured in this winter.
\end{abstract}

\section{Introduction}

Although Lagrangian models have several advantages over grid-based Eulerian models (e.g. no numerical diffusion, no negative species concentrations by transport, easy parallelization), only few Lagrangian CTMs are in use so far, including the STOCHEM (e.g. Collins et al., 1997), ATTILA (e.g. Reithmeier and Sausen, 2002) and CLaMS (e.g. Konopka et al., 2004) models. ATLAS is a new global Lagrangian CTM with a focus on the stratosphere.

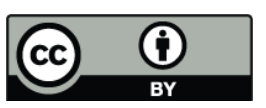

Correspondence to: I. Wohltmann (ingo.wohltmann@awi.de)
This is the second part of the model description of the ATLAS model, which focusses on the stratospheric chemistry module. The implementation of transport and mixing was already described in Wohltmann and Rex (2009). The model architecture of ATLAS shares a number of concepts with the CLaMS 3-D model (see Konopka et al., 2004, 2007 for general aspects and McKenna et al., 2002 and Grooß et al., 2002, 2005 for the chemistry), but ATLAS is an independently developed model with no code in common with CLaMS.

Figure 1 shows the basic layout of the model. A large number of trajectories, each representing an air parcel, is initialized and advected for some hours (filling the domain of the complete atmosphere) (trajectory module, light blue box). Chemistry is simulated on every trajectory like in a box model (chemistry module, yellow box), followed by the calculation of the growth and sedimentation of polar stratospheric cloud particles (brown box). Every few hours, a mixing step is introduced (mixing module, orange box), where air parcels are mixed in regions of large flow deformation (determined by Lyapunov exponent) to obtain a realistic diffusion of species.

The stratospheric chemistry module is based on a box model with a rather extensive set of 171 reactions and 46 active species and includes a detailed treatment of heterogeneous chemistry on polar stratospheric clouds based on the module by Carslaw et al. (1995). The implementation of the denitrification module is based on the DLAPSE particle model of Carslaw et al. (2002). The system of differential equations is solved by a stiff solver with a variable time step without using the concept of chemical families.

Model runs covering the Arctic winter 1999/2000 driven by winds and temperatures from ECMWF ERA Interim reanalysis data (Simmons et al., 2006) are conducted to assess the performance of the chemistry and denitrification modules. The winter of 1999/2000 has been chosen for several reasons: thanks to the SOLVE/THESEO 2000 measurement

Published by Copernicus Publications on behalf of the European Geosciences Union. 


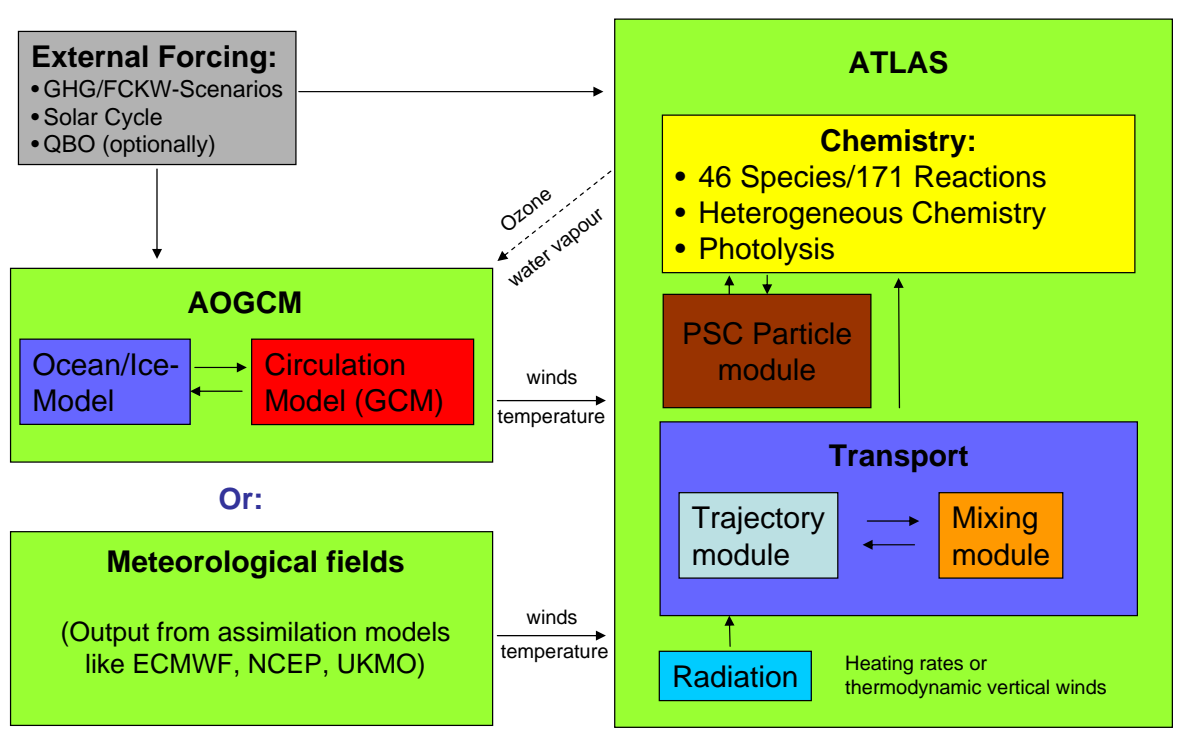

Fig. 1. Model concept.

Table 1. Species considered in the chemistry scheme.

\begin{tabular}{ll}
\hline Category & Species \\
\hline Long-lived & $\mathrm{CH}_{4}, \mathrm{H}_{2} \mathrm{O}, \mathrm{N}_{2} \mathrm{O}, \mathrm{CO}_{2}, \mathrm{CO}, \mathrm{H}_{2}$ \\
Halogen sources & $\mathrm{CFC}-11, \mathrm{CFC}-12, \mathrm{CFC}-113, \mathrm{HCFC}-22, \mathrm{CH}_{3} \mathrm{Cl}, \mathrm{CH}_{3} \mathrm{Br}, \mathrm{CCl}_{4}$, \\
& $\mathrm{CH}_{3} \mathrm{CCl}$, Halon-1211, Halon-1301 \\
Oxygen & $\mathrm{O}_{3}, \mathrm{O}\left({ }^{3} \mathrm{P}\right), \mathrm{O}\left({ }^{1} \mathrm{D}\right)$ \\
Nitrogen & $\mathrm{NO}, \mathrm{NO}_{2}, \mathrm{NO}_{3}, \mathrm{~N}_{2} \mathrm{O}_{5}, \mathrm{HNO}_{3}, \mathrm{HO}_{2} \mathrm{NO}_{2}, \mathrm{~N}$ \\
Hydrogen & $\mathrm{H}, \mathrm{OH}, \mathrm{HO}_{2}, \mathrm{H}_{2} \mathrm{O}_{2}, \mathrm{CH}_{2} \mathrm{O}$ \\
Chlorine & $\mathrm{Cl}, \mathrm{Cl} 2, \mathrm{ClO}, \mathrm{OClO}, \mathrm{Cl}_{2} \mathrm{O}_{2}, \mathrm{HCl}, \mathrm{HOCl}, \mathrm{ClONO}_{2}, \mathrm{ClNO}_{2}$ \\
Bromine & $\mathrm{Br}, \mathrm{BrCl}, \mathrm{BrO}, \mathrm{HBr}, \mathrm{HOBr}, \mathrm{BrONO}$ \\
Fixed & $\mathrm{O}_{2}, \mathrm{~N}_{2}$ \\
\hline
\end{tabular}

campaign (Newman et al., 2002), there is an unrivalled wealth of measurements available, which is beneficial both for initialization and validation. In addition, the winter was one of the coldest stratospheric winters on record, with one of the largest amounts of ozone loss measured so far (e.g. Rex et al., 2002). It was also one of the few winters where substantial denitrification occured in the Northern Hemisphere (Popp et al., 2001), which prolonged the period of stratospheric ozone loss, and it saw the discovery of the so-called "NAT rocks" (large nitric acid trihydrate particles) as the probable cause for this denitrification (Fahey et al., 2001).

A detailed description of the chemistry module and the Lagrangian denitrification module is given in Sect. 2. The setup of the performed model runs is described in Sect. 3. Results of model runs covering the winter 1999/2000 are presented in Sect. 4 and compared to observations. Conclusions are given in Sect. 5. Additionally, a Supplement is provided with the paper, which includes figures of all comparisons of model data to measurements performed for this study.

\section{Model description}

The chemistry module is based on the stratospheric box model of the Alfred Wegener Institute (see model comparison by Krämer et al., 2003; Lehmann, 2004). It contains 46 active species and 2 fixed species, which are shown in Table 1 . The model incorporates 171 reactions, including 42 photolysis reactions (Table 2), 122 gas phase reactions (Table 3) and 7 heterogeneous reactions (Table 4). Note that several equations are given as net equations summarizing the products of an intermediate chain of reactions (in this case, the number of $\mathrm{N}$ and $\mathrm{O}$ atoms on the left and right hand side of the equation may also differ. These are taken implicitly from the fixed species $\mathrm{N}_{2}$ and $\mathrm{O}_{2}$ ). 
Table 2. List of photolysis reactions.

\begin{tabular}{|c|c|c|}
\hline Reaction & & \\
\hline $\mathrm{O}_{2}+h v$ & $\rightarrow$ & $\mathrm{O}\left({ }^{3} \mathrm{P}\right)+\mathrm{O}\left({ }^{3} \mathrm{P}\right)$ \\
\hline $\mathrm{O}_{3}+h v$ & $\rightarrow$ & $\mathrm{O}\left({ }^{3} \mathrm{P}\right)+\mathrm{O}_{2}$ \\
\hline $\mathrm{H}_{2} \mathrm{O}+h v$ & $\rightarrow$ & $\mathrm{OH}+\mathrm{H}$ \\
\hline $\mathrm{N}_{2} \mathrm{O}+h v$ & $\rightarrow$ & $\mathrm{N}_{2}+\mathrm{O}\left({ }^{1} \mathrm{D}\right)$ \\
\hline $\mathrm{CH}_{4}+h v$ & $\rightarrow$ & $\mathrm{CO}+2 \mathrm{H}_{2} \mathrm{O}$ \\
\hline $\mathrm{NO}_{2}+h v$ & $\rightarrow$ & $\mathrm{NO}+\mathrm{O}\left({ }^{3} \mathrm{P}\right)$ \\
\hline $\mathrm{HNO}_{3}+h v$ & $\rightarrow$ & $\mathrm{NO}_{2}+\mathrm{OH}$ \\
\hline $\mathrm{HOCl}+h v$ & $\rightarrow$ & $\mathrm{Cl}+\mathrm{OH}$ \\
\hline $\mathrm{HO}_{2} \mathrm{NO}_{2}+h v$ & $\rightarrow$ & $\mathrm{HO}_{2}+\mathrm{NO}_{2}$ \\
\hline $\mathrm{HO}_{2} \mathrm{NO}_{2}+h v$ & $\rightarrow$ & $\mathrm{OH}+\mathrm{NO}_{3}$ \\
\hline $\mathrm{ClONO}_{2}+h v$ & $\rightarrow$ & $\mathrm{Cl}+\mathrm{NO}_{3}$ \\
\hline $\mathrm{ClONO}_{2}+h v$ & $\rightarrow$ & $\mathrm{ClO}+\mathrm{NO}_{2}$ \\
\hline $\mathrm{N}_{2} \mathrm{O}_{5}+h v$ & $\rightarrow$ & $\mathrm{NO}_{2}+\mathrm{NO}_{3}$ \\
\hline $\mathrm{N}_{2} \mathrm{O}_{5}+h v$ & $\rightarrow$ & $\mathrm{NO}+\mathrm{NO}_{3}+\mathrm{O}\left({ }^{3} \mathrm{P}\right)$ \\
\hline $\mathrm{O}_{3}+h v$ & $\rightarrow$ & $\mathrm{O}\left({ }^{1} \mathrm{D}\right)+\mathrm{O}_{2}$ \\
\hline $\mathrm{H}_{2} \mathrm{O}_{2}+h v$ & $\rightarrow$ & $\mathrm{OH}+\mathrm{OH}$ \\
\hline $\mathrm{OClO}+h v$ & $\rightarrow$ & $\mathrm{ClO}+\mathrm{O}\left({ }^{3} \mathrm{P}\right)$ \\
\hline $\mathrm{Cl}_{2} \mathrm{O}_{2}+h v$ & $\rightarrow$ & $\mathrm{Cl}+\mathrm{Cl}+\mathrm{O}_{2}$ \\
\hline $\mathrm{HCl}+h v$ & $\rightarrow$ & $\mathrm{Cl}+\mathrm{H}$ \\
\hline $\mathrm{Cl}_{2}+h v$ & $\rightarrow$ & $\mathrm{Cl}+\mathrm{Cl}$ \\
\hline $\mathrm{CO}_{2}+h v$ & $\rightarrow$ & $\mathrm{CO}+\mathrm{O}\left({ }^{3} \mathrm{P}\right)$ \\
\hline $\mathrm{ClNO}_{2}+h v$ & $\rightarrow$ & $\mathrm{Cl}+\mathrm{NO}_{2}$ \\
\hline $\mathrm{BrONO}_{2}+h v$ & $\rightarrow$ & $\mathrm{BrO}+\mathrm{NO}_{2}$ \\
\hline $\mathrm{BrONO}_{2}+h v$ & $\rightarrow$ & $\mathrm{Br}+\mathrm{NO}_{3}$ \\
\hline $\mathrm{BrCl}+h v$ & $\rightarrow$ & $\mathrm{Br}+\mathrm{Cl}$ \\
\hline $\mathrm{HOBr}+h v$ & $\rightarrow$ & $\mathrm{Br}+\mathrm{OH}$ \\
\hline $\mathrm{CH}_{2} \mathrm{O}+h v$ & $\rightarrow$ & $\mathrm{H}+\mathrm{CO}+\mathrm{HO}_{2}$ \\
\hline $\mathrm{CH}_{2} \mathrm{O}+h v$ & $\rightarrow$ & $\mathrm{H}_{2}+\mathrm{CO}$ \\
\hline $\mathrm{NO}+h v$ & $\rightarrow$ & $\mathrm{N}+\mathrm{O}\left({ }^{3} \mathrm{P}\right)$ \\
\hline $\mathrm{BrO}+h v$ & $\rightarrow$ & $\mathrm{Br}+\mathrm{O}\left({ }^{3} \mathrm{P}\right)$ \\
\hline $\mathrm{NO}_{3}+h v$ & $\rightarrow$ & $\mathrm{NO}_{2}+\mathrm{O}\left({ }^{3} \mathrm{P}\right)$ \\
\hline $\mathrm{NO}_{3}+h v$ & $\rightarrow$ & $\mathrm{NO}+\mathrm{O}_{2}$ \\
\hline $\mathrm{CFC}-11+h v$ & $\rightarrow$ & $3 \mathrm{Cl}+$ products \\
\hline $\mathrm{CFC}-12+h v$ & $\rightarrow$ & $2 \mathrm{Cl}+$ products \\
\hline $\mathrm{CFC}-113+h v$ & $\rightarrow$ & $3 \mathrm{Cl}+$ products \\
\hline $\mathrm{HCFC}-22+h v$ & $\rightarrow$ & $\mathrm{Cl}+$ products \\
\hline $\mathrm{CH}_{3} \mathrm{Cl}+h v$ & $\rightarrow$ & $\mathrm{Cl}+$ products \\
\hline $\mathrm{CCl}_{4}+h v$ & $\rightarrow$ & $4 \mathrm{Cl}+$ products \\
\hline $\mathrm{CH}_{3} \mathrm{CCl}_{3}+h v$ & $\rightarrow$ & $3 \mathrm{Cl}+$ products \\
\hline Halon-1211 $+h v$ & $\rightarrow$ & $\mathrm{Br}+\mathrm{Cl}+$ products \\
\hline Halon-1301 + hv & $\rightarrow$ & $\mathrm{Br}+$ products \\
\hline $\mathrm{CH}_{3} \mathrm{Br}+h v$ & $\rightarrow$ & $\mathrm{Br}+$ products \\
\hline
\end{tabular}

All rate constants are set to the recommendations in the JPL 2006 catalogue (Sander et al., 2006) and its 2009 update (Sander et al., 2009).

The system of differential equations needed for the time integration has been created from the list of reactions using the Kinetic PreProcessor (KPP) (Sandu and Sander, 2006). The chemistry module uses a stiff solver for solving the differential equations, so no grouping in families is needed to allow for large integration time steps. The stiff solver is based on the Numerical Differentiation Formulas (NDFs) and uses an automatic adaptive time step (Shampine and Reichelt, 1997). A constraint on positive mixing ratios is built directly into the solver. The box model runs are parallelized.

\subsection{Photolysis}

Photolysis rates are interpolated from a 4-D look-up table as a function of pressure, temperature, solar zenith angle and overhead ozone column. Overhead ozone is calculated interactively from the ozone mixing ratios of the model. The photolysis table is based on absorption cross sections from JPL 2006 (Sander et al., 2006), except for $\mathrm{Cl}_{2} \mathrm{O}_{2}$, which are from Burkholder et al. (1990). The radiative transfer model TUV (Madronich and Flocke, 1999) is used to compute the photolysis rates. The table allows solar zenith angles of up to $98^{\circ}$ to account for photochemistry under twilight conditions in the polar night.

\subsection{Heterogeneous chemistry}

The heterogeneous chemistry module is based on the equilibrium scheme by Carslaw et al. (1995). Three types of aerosols are considered: liquid ternary $\mathrm{H}_{2} \mathrm{SO}_{4}-\mathrm{HNO}_{3}-\mathrm{H}_{2} \mathrm{O}$ solutions, solid nitric acid trihydrate (NAT) particles and solid water ice particles.

The existence and composition of ternary solutions is calculated according to Carslaw et al. (1995). $\mathrm{H}_{2} \mathrm{SO}_{4}$ (assumed to be completely in the liquid phase) is taken from a simple climatology with a constant bell shaped profile relative to the mean tropopause which peaks at $0.5 \mathrm{ppb}$ and has a vertical half width of about $5 \mathrm{~km}$. The initial number density of droplets for ternary solutions is set to $10 \mathrm{~cm}^{-3}$. Surface area densities of the liquid aerosols can either be calculated in the module from the input parameters (assuming a lognormal distribution of droplet radii) or can be prescribed from measurements. A surface area density climatology based on SAGE data including volcanic aerosols is included in the model (Eyring et al., 2008). Ternary solutions are formed between $240 \mathrm{~K}$ and the formation temperature of ice.

NAT particles form if the saturation mixing ratio of $\mathrm{HNO}_{3}$ over NAT is exceeded by a factor determined from a given supersaturation. Similarly, ice particles form if the saturation mixing ratio of $\mathrm{H}_{2} \mathrm{O}$ over ice is exceeded by a given factor. Saturation mixing ratios (respectively formation temperatures $T_{\mathrm{NAT}}$ and $T_{\text {ice }}$ ) are calculated from the expressions in Hanson and Mauersberger (1988) and Marti and Mauersberger (1993). If NAT and liquid particles coexist, NAT particles are formed from the supercooled ternary solution droplets and the number density of the droplets and the available $\mathrm{H}_{2} \mathrm{SO}_{4}$ is adjusted accordingly. NAT surface area densities are calculated from the available $\mathrm{HNO}_{3}$ by assuming a particle number density of $1 \mathrm{~cm}^{-3}$ and a uniform particle radius. Below $T_{\text {ice}}$, water ice clouds form in addition 
Table 3. List of gas phase reactions.

\begin{tabular}{|c|c|c|c|c|c|}
\hline \multicolumn{3}{|l|}{ Reaction } & \multicolumn{3}{|l|}{ Reaction } \\
\hline $\mathrm{O}\left({ }^{3} \mathrm{P}\right)+\mathrm{O}\left({ }^{3} \mathrm{P}\right)+\mathrm{M}$ & $\rightarrow$ & $\mathrm{O}_{2}+\mathrm{M}$ & $\mathrm{CH}_{2} \mathrm{O}+\mathrm{Cl}$ & $\rightarrow$ & $\mathrm{HCl}+\mathrm{CO}+\mathrm{HO}_{2}$ \\
\hline $\mathrm{O}\left({ }^{3} \mathrm{P}\right)+\mathrm{O}_{2}+\mathrm{M}$ & $\rightarrow$ & $\mathrm{O}_{3}+\mathrm{M}$ & $\mathrm{OH}+\mathrm{HCl}$ & $\rightarrow$ & $\mathrm{H}_{2} \mathrm{O}+\mathrm{Cl}$ \\
\hline $\mathrm{O}\left({ }^{3} \mathrm{P}\right)+\mathrm{O}_{3}$ & $\rightarrow$ & $\mathrm{O}_{2}+\mathrm{O}_{2}$ & $\mathrm{ClO}+\mathrm{NO}_{2}+\mathrm{M}$ & $\rightarrow$ & $\mathrm{ClONO}_{2}+\mathrm{M}$ \\
\hline $\mathrm{O}\left({ }^{1} \mathrm{D}\right)+\mathrm{N}_{2}$ & $\rightarrow$ & $\mathrm{O}\left({ }^{3} \mathrm{P}\right)+\mathrm{N}_{2}$ & $\mathrm{O}\left({ }^{3} \mathrm{P}\right)+\mathrm{ClONO}_{2}$ & $\rightarrow$ & $\mathrm{ClO}+\mathrm{NO}_{3}$ \\
\hline $\mathrm{O}\left({ }^{1} \mathrm{D}\right)+\mathrm{O}_{2}$ & $\rightarrow$ & $\mathrm{O}\left({ }^{3} \mathrm{P}\right)+\mathrm{O}_{2}$ & $\mathrm{ClO}+\mathrm{HO}_{2}$ & $\rightarrow$ & $\mathrm{HOCl}+\mathrm{O}_{2}$ \\
\hline $\mathrm{O}\left({ }^{1} \mathrm{D}\right)+\mathrm{O}_{3}$ & $\rightarrow$ & $\mathrm{O}_{2}+\mathrm{O}_{2}$ & $\mathrm{OH}+\mathrm{HOCl}$ & $\rightarrow$ & $\mathrm{H}_{2} \mathrm{O}+\mathrm{ClO}$ \\
\hline $\mathrm{O}\left({ }^{1} \mathrm{D}\right)+\mathrm{N}_{2}+\mathrm{M}$ & $\rightarrow$ & $\mathrm{N}_{2} \mathrm{O}+\mathrm{M}$ & $\mathrm{O}\left({ }^{3} \mathrm{P}\right)+\mathrm{HOCl}$ & $\rightarrow$ & $\mathrm{OH}+\mathrm{ClO}$ \\
\hline $\mathrm{O}\left({ }^{1} \mathrm{D}\right)+\mathrm{H}_{2} \mathrm{O}$ & $\rightarrow$ & $\mathrm{OH}+\mathrm{OH}$ & $\mathrm{Cl}+\mathrm{NO}_{2}+\mathrm{M}$ & $\rightarrow$ & $\mathrm{ClNO}_{2}+\mathrm{M}$ \\
\hline $\mathrm{O}\left({ }^{1} \mathrm{D}\right)+\mathrm{CH}_{4}$ & $\rightarrow$ & $\mathrm{OH}+\mathrm{CH}_{2} \mathrm{O}+\mathrm{HO}_{2}$ & $\mathrm{Cl}+\mathrm{HOCl}$ & $\rightarrow$ & $\mathrm{OH}+\mathrm{Cl}_{2}$ \\
\hline $\mathrm{O}\left({ }^{1} \mathrm{D}\right)+\mathrm{H}_{2}$ & $\rightarrow$ & $\mathrm{OH}+\mathrm{H}$ & $\mathrm{ClO}+\mathrm{OH}$ & $\rightarrow$ & $\mathrm{HCl}+\mathrm{O}_{2}$ \\
\hline $\mathrm{H}+\mathrm{O}_{2}+\mathrm{M}$ & $\rightarrow$ & $\mathrm{HO}_{2}+\mathrm{M}$ & $\mathrm{ClO}+\mathrm{ClO}$ & $\rightarrow$ & $\mathrm{Cl}+\mathrm{OClO}$ \\
\hline $\mathrm{H}+\mathrm{O}_{3}$ & $\rightarrow$ & $\mathrm{OH}+\mathrm{O}_{2}$ & $\mathrm{ClO}+\mathrm{ClO}$ & $\rightarrow$ & $\mathrm{Cl}_{2}+\mathrm{O}_{2}$ \\
\hline $\mathrm{O}\left({ }^{3} \mathrm{P}\right)+\mathrm{OH}$ & $\rightarrow$ & $\mathrm{O}_{2}+\mathrm{H}$ & $\mathrm{ClO}+\mathrm{ClO}+\mathrm{M}$ & $\rightarrow$ & $\mathrm{Cl}_{2} \mathrm{O}_{2}+\mathrm{M}$ \\
\hline $\mathrm{OH}+\mathrm{O}_{3}$ & $\rightarrow$ & $\mathrm{HO}_{2}+\mathrm{O}_{2}$ & $\mathrm{Cl}_{2} \mathrm{O}_{2}+\mathrm{M}$ & $\rightarrow$ & $\mathrm{ClO}+\mathrm{ClO}+\mathrm{M}$ \\
\hline $\mathrm{HO}_{2}+\mathrm{O}_{3}$ & $\rightarrow$ & $\mathrm{OH}+\mathrm{O}_{2}+\mathrm{O}_{2}$ & $\mathrm{OClO}+\mathrm{OH}$ & $\rightarrow$ & $\mathrm{HOCl}+\mathrm{O}_{2}$ \\
\hline $\mathrm{O}\left({ }^{3} \mathrm{P}\right)+\mathrm{HO}_{2}$ & $\rightarrow$ & $\mathrm{OH}+\mathrm{O}_{2}$ & $\mathrm{Cl}+\mathrm{OClO}$ & $\rightarrow$ & $\mathrm{ClO}+\mathrm{ClO}$ \\
\hline $\mathrm{OH}+\mathrm{HO}_{2}$ & $\rightarrow$ & $\mathrm{H}_{2} \mathrm{O}+\mathrm{O}_{2}$ & $\mathrm{OClO}+\mathrm{O}\left({ }^{3} \mathrm{P}\right)$ & $\rightarrow$ & $\mathrm{ClO}+\mathrm{O}_{2}$ \\
\hline $\mathrm{OH}+\mathrm{H}_{2}$ & $\rightarrow$ & $\mathrm{H}_{2} \mathrm{O}+\mathrm{H}$ & $\mathrm{OClO}+\mathrm{NO}$ & $\rightarrow$ & $\mathrm{NO}_{2}+\mathrm{ClO}$ \\
\hline $\mathrm{H}+\mathrm{HO}_{2}$ & $\rightarrow$ & $\mathrm{OH}+\mathrm{OH}$ & $\mathrm{Cl}_{2}+\mathrm{O}\left({ }^{1} \mathrm{D}\right)$ & $\rightarrow$ & $\mathrm{Cl}+\mathrm{ClO}$ \\
\hline $\mathrm{H}+\mathrm{HO}_{2}$ & $\rightarrow$ & $\mathrm{H}_{2}+\mathrm{O}_{2}$ & $\mathrm{Cl}+\mathrm{Cl}_{2} \mathrm{O}_{2}$ & $\rightarrow$ & $\mathrm{Cl}_{2}+\mathrm{Cl}+\mathrm{O}_{2}$ \\
\hline $\mathrm{H}+\mathrm{HO}_{2}$ & $\rightarrow$ & $\mathrm{H}_{2} \mathrm{O}+\mathrm{O}\left({ }^{3} \mathrm{P}\right)$ & $\mathrm{Cl}+\mathrm{NO}_{3}$ & $\rightarrow$ & $\mathrm{ClO}+\mathrm{NO}_{2}$ \\
\hline $\mathrm{H}_{2}+\mathrm{O}\left({ }^{3} \mathrm{P}\right)$ & $\rightarrow$ & $\mathrm{OH}+\mathrm{H}$ & $\mathrm{ClO}+\mathrm{NO}_{3}$ & $\rightarrow$ & $\mathrm{Cl}+\mathrm{NO}_{2}+\mathrm{O}_{2}$ \\
\hline $\mathrm{NO}+\mathrm{HO}_{2}$ & $\rightarrow$ & $\mathrm{NO}_{2}+\mathrm{OH}$ & $\mathrm{O}\left({ }^{1} \mathrm{D}\right)+\mathrm{HCl}$ & $\rightarrow$ & $\mathrm{OH}+\mathrm{Cl}$ \\
\hline $\mathrm{HO}_{2}+\mathrm{HO}_{2}$ & $\rightarrow$ & $\mathrm{H}_{2} \mathrm{O}_{2}+\mathrm{O}_{2}$ & $\mathrm{Cl}_{2}+\mathrm{OH}$ & $\rightarrow$ & $\mathrm{HOCl}+\mathrm{Cl}$ \\
\hline $\mathrm{OH}+\mathrm{H}_{2} \mathrm{O}_{2}$ & $\rightarrow$ & $\mathrm{H}_{2} \mathrm{O}+\mathrm{HO}_{2}$ & $\mathrm{Cl}+\mathrm{ClONO}_{2}$ & $\rightarrow$ & $\mathrm{Cl}_{2}+\mathrm{NO}_{3}$ \\
\hline $\mathrm{OH}+\mathrm{CO}$ & $\rightarrow$ & $\mathrm{CO}_{2}+\mathrm{H}$ & $\mathrm{Cl}+\mathrm{HO}_{2}$ & $\rightarrow$ & $\mathrm{ClO}+\mathrm{OH}$ \\
\hline $\mathrm{OH}+\mathrm{CO}$ & $\rightarrow$ & $\mathrm{CO}_{2}+\mathrm{HO}_{2}$ & $\mathrm{Cl}+\mathrm{H}_{2} \mathrm{O}_{2}$ & $\rightarrow$ & $\mathrm{HCl}+\mathrm{HO}_{2}$ \\
\hline $\mathrm{H}_{2} \mathrm{O}_{2}+\mathrm{O}\left({ }^{3} \mathrm{P}\right)$ & $\rightarrow$ & $\mathrm{OH}+\mathrm{HO}_{2}$ & $\mathrm{O}\left({ }^{3} \mathrm{P}\right)+\mathrm{HCl}$ & $\rightarrow$ & $\mathrm{OH}+\mathrm{Cl}$ \\
\hline $\mathrm{OH}+\mathrm{OH}$ & $\rightarrow$ & $\mathrm{O}\left({ }^{3} \mathrm{P}\right)+\mathrm{H}_{2} \mathrm{O}$ & $\mathrm{OH}+\mathrm{ClONO}_{2}$ & $\rightarrow$ & $\mathrm{HOCl}+\mathrm{NO}_{3}$ \\
\hline $\mathrm{OH}+\mathrm{OH}+\mathrm{M}$ & $\rightarrow$ & $\mathrm{H}_{2} \mathrm{O}_{2}+\mathrm{M}$ & $\mathrm{Br}+\mathrm{O}_{3}$ & $\rightarrow$ & $\mathrm{BrO}+\mathrm{O}_{2}$ \\
\hline $\mathrm{O}\left({ }^{3} \mathrm{P}\right)+\mathrm{NO}_{2}$ & $\rightarrow$ & $\mathrm{NO}+\mathrm{O}_{2}$ & $\mathrm{BrO}+\mathrm{O}\left({ }^{3} \mathrm{P}\right)$ & $\rightarrow$ & $\mathrm{Br}+\mathrm{O}_{2}$ \\
\hline $\mathrm{O}_{3}+\mathrm{NO}$ & $\rightarrow$ & $\mathrm{NO}_{2}+\mathrm{O}_{2}$ & $\mathrm{BrO}+\mathrm{NO}$ & $\rightarrow$ & $\mathrm{NO}_{2}+\mathrm{Br}$ \\
\hline $\mathrm{N}+\mathrm{NO}$ & $\rightarrow$ & $\mathrm{N}_{2}+\mathrm{O}\left({ }^{3} \mathrm{P}\right)$ & $\mathrm{BrO}+\mathrm{ClO}$ & $\rightarrow$ & $\mathrm{OClO}+\mathrm{Br}$ \\
\hline $\mathrm{N}+\mathrm{O}_{2}$ & $\rightarrow$ & $\mathrm{NO}+\mathrm{O}\left({ }^{3} \mathrm{P}\right)$ & $\mathrm{BrO}+\mathrm{ClO}$ & $\rightarrow$ & $\mathrm{Br}+\mathrm{Cl}+\mathrm{O}_{2}$ \\
\hline $\mathrm{O}_{3}+\mathrm{NO}_{2}$ & $\rightarrow$ & $\mathrm{NO}_{3}+\mathrm{O}_{2}$ & $\mathrm{BrO}+\mathrm{ClO}$ & $\rightarrow$ & $\mathrm{BrCl}+\mathrm{O}_{2}$ \\
\hline $\mathrm{NO}_{2}+\mathrm{NO}_{3}+\mathrm{M}$ & $\rightarrow$ & $\mathrm{N}_{2} \mathrm{O}_{5}+\mathrm{M}$ & $\mathrm{BrO}+\mathrm{BrO}$ & $\rightarrow$ & $\mathrm{Br}+\mathrm{Br}+\mathrm{O}_{2}$ \\
\hline $\mathrm{OH}+\mathrm{NO}_{2}+\mathrm{M}$ & $\rightarrow$ & $\mathrm{HNO}_{3}+\mathrm{M}$ & $\mathrm{Br}+\mathrm{HO}_{2}$ & $\rightarrow$ & $\mathrm{HBr}+\mathrm{O}_{2}$ \\
\hline $\mathrm{HO}_{2}+\mathrm{NO}_{2}+\mathrm{M}$ & $\rightarrow$ & $\mathrm{HO}_{2} \mathrm{NO}_{2}+\mathrm{M}$ & $\mathrm{Br}+\mathrm{OClO}$ & $\rightarrow$ & $\mathrm{BrO}+\mathrm{ClO}$ \\
\hline $\mathrm{HO}_{2} \mathrm{NO}_{2}+\mathrm{M}$ & $\rightarrow$ & $\mathrm{HO}_{2}+\mathrm{NO}_{2}+\mathrm{M}$ & $\mathrm{Br}+\mathrm{CH}_{2} \mathrm{O}$ & $\rightarrow$ & $\mathrm{HBr}+\mathrm{CO}+\mathrm{HO}_{2}$ \\
\hline $\mathrm{HNO}_{3}+\mathrm{OH}$ & $\rightarrow$ & $\mathrm{H}_{2} \mathrm{O}+\mathrm{NO}_{3}$ & $\mathrm{OH}+\mathrm{HBr}$ & $\rightarrow$ & $\mathrm{H}_{2} \mathrm{O}+\mathrm{Br}$ \\
\hline $\mathrm{OH}+\mathrm{HO}_{2} \mathrm{NO}_{2}$ & $\rightarrow$ & $\mathrm{H}_{2} \mathrm{O}+\mathrm{NO}_{2}+\mathrm{O}_{2}$ & $\mathrm{BrO}+\mathrm{NO}_{2}+\mathrm{M}$ & $\rightarrow$ & $\mathrm{BrONO}_{2}+\mathrm{M}$ \\
\hline $\mathrm{N}_{2} \mathrm{O}_{5}+\mathrm{M}$ & $\rightarrow$ & $\mathrm{NO}_{2}+\mathrm{NO}_{3}+\mathrm{M}$ & $\mathrm{BrO}+\mathrm{HO}_{2}$ & $\rightarrow$ & $\mathrm{HOBr}+\mathrm{O}_{2}$ \\
\hline $\mathrm{O}\left({ }^{1} \mathrm{D}\right)+\mathrm{N}_{2} \mathrm{O}$ & $\rightarrow$ & $\mathrm{N}_{2}+\mathrm{O}_{2}$ & $\mathrm{HBr}+\mathrm{O}\left({ }^{1} \mathrm{D}\right)$ & $\rightarrow$ & $\mathrm{Br}+\mathrm{OH}$ \\
\hline $\mathrm{O}\left({ }^{1} \mathrm{D}\right)+\mathrm{N}_{2} \mathrm{O}$ & $\rightarrow$ & $\mathrm{NO}+\mathrm{NO}$ & $\mathrm{BrO}+\mathrm{OH}$ & $\rightarrow$ & $\mathrm{Br}+\mathrm{HO}_{2}$ \\
\hline $\mathrm{O}\left({ }^{3} \mathrm{P}\right)+\mathrm{NO}_{3}$ & $\rightarrow$ & $\mathrm{NO}_{2}+\mathrm{O}_{2}$ & $\mathrm{HBr}+\mathrm{O}\left({ }^{3} \mathrm{P}\right)$ & $\rightarrow$ & $\mathrm{Br}+\mathrm{OH}$ \\
\hline $\mathrm{OH}+\mathrm{NO}_{3}$ & $\rightarrow$ & $\mathrm{NO}_{2}+\mathrm{HO}_{2}$ & $\mathrm{BrONO}_{2}+\mathrm{O}\left({ }^{3} \mathrm{P}\right)$ & $\rightarrow$ & $\mathrm{BrO}+\mathrm{NO}_{3}$ \\
\hline $\mathrm{HO}_{2}+\mathrm{NO}_{3}$ & $\rightarrow$ & $\mathrm{NO}_{2}+\mathrm{OH}+\mathrm{O}_{2}$ & $\mathrm{H}+\mathrm{NO}_{2}$ & $\rightarrow$ & $\mathrm{NO}+\mathrm{OH}$ \\
\hline $\mathrm{HO}_{2}+\mathrm{NO}_{3}$ & $\rightarrow$ & $\mathrm{HNO}_{3}+\mathrm{O}_{2}$ & $\mathrm{~N}+\mathrm{NO}_{2}$ & $\rightarrow$ & $\mathrm{N}_{2} \mathrm{O}+\mathrm{O}\left({ }^{3} \mathrm{P}\right)$ \\
\hline $\mathrm{NO}_{2}+\mathrm{O}\left({ }^{3} \mathrm{P}\right)+\mathrm{M}$ & $\rightarrow$ & $\mathrm{NO}_{3}+\mathrm{M}$ & $\mathrm{OClO}+\mathrm{O}_{3}$ & $\rightarrow$ & $\mathrm{ClO}+\mathrm{O}_{2}+\mathrm{O}_{2}$ \\
\hline $\mathrm{NO}+\mathrm{O}\left({ }^{3} \mathrm{P}\right)+\mathrm{M}$ & $\rightarrow$ & $\mathrm{NO}_{2}+\mathrm{M}$ & $\mathrm{O}\left({ }^{1} \mathrm{D}\right)+\mathrm{O}_{3}$ & $\rightarrow$ & $\mathrm{O}\left({ }^{3} \mathrm{P}\right)+\mathrm{O}\left({ }^{3} \mathrm{P}\right)+\mathrm{O}_{2}$ \\
\hline $\mathrm{NO}+\mathrm{NO}_{3}$ & $\rightarrow$ & $\mathrm{NO}_{2}+\mathrm{NO}_{2}$ & $\mathrm{ClO}+\mathrm{O}_{3}$ & $\rightarrow$ & $\mathrm{Cl}+\mathrm{O}_{2}+\mathrm{O}_{2}$ \\
\hline $\mathrm{CH}_{4}+\mathrm{OH}$ & $\rightarrow$ & $\mathrm{CH}_{2} \mathrm{O}+\mathrm{HO}_{2}$ & $\mathrm{CFC}-11+\mathrm{O}\left({ }^{1} \mathrm{D}\right)$ & $\rightarrow$ & $3 \mathrm{Cl}+$ products \\
\hline $\mathrm{OH}+\mathrm{CH}_{2} \mathrm{O}$ & $\rightarrow$ & $\mathrm{CO}+\mathrm{HO}_{2}+\mathrm{H}_{2} \mathrm{O}$ & $\mathrm{CFC}-12+\mathrm{O}\left({ }^{1} \mathrm{D}\right)$ & $\rightarrow$ & $2 \mathrm{Cl}+$ products \\
\hline $\mathrm{O}\left({ }^{3} \mathrm{P}\right)+\mathrm{CH}_{2} \mathrm{O}$ & $\rightarrow$ & $\mathrm{CO}+\mathrm{HO}_{2}+\mathrm{OH}$ & $\mathrm{CFC}-113+\mathrm{O}\left({ }^{1} \mathrm{D}\right)$ & $\rightarrow$ & $3 \mathrm{Cl}+$ products \\
\hline $\mathrm{Cl}+\mathrm{O}_{3}$ & $\rightarrow$ & $\mathrm{ClO}+\mathrm{O}_{2}$ & $\mathrm{HCFC}-22+\mathrm{O}\left({ }^{1} \mathrm{D}\right)$ & $\rightarrow$ & $\mathrm{Cl}+$ products \\
\hline $\mathrm{ClO}+\mathrm{O}\left({ }^{3} \mathrm{P}\right)$ & $\rightarrow$ & $\mathrm{Cl}+\mathrm{O}_{2}$ & $\mathrm{HCFC}-22+\mathrm{OH}$ & $\rightarrow$ & $\mathrm{Cl}+$ products \\
\hline $\mathrm{ClO}+\mathrm{NO}$ & $\rightarrow$ & $\mathrm{NO}_{2}+\mathrm{Cl}$ & $\mathrm{CH}_{3} \mathrm{Cl}+\mathrm{OH}$ & $\rightarrow$ & $\mathrm{Cl}+$ products \\
\hline $\mathrm{Cl}+\mathrm{CH}_{4}$ & $\rightarrow$ & $\mathrm{HCl}+\mathrm{CH}_{2} \mathrm{O}+\mathrm{HO}_{2}$ & $\mathrm{CCl}_{4}+\mathrm{O}\left({ }^{1} \mathrm{D}\right)$ & $\rightarrow$ & $4 \mathrm{Cl}+$ products \\
\hline $\mathrm{Cl}+\mathrm{H}_{2}$ & $\rightarrow$ & $\mathrm{HCl}+\mathrm{H}$ & $\mathrm{CH}_{3} \mathrm{CCl}_{3}+\mathrm{OH}$ & $\rightarrow$ & $3 \mathrm{Cl}+$ products \\
\hline $\mathrm{Cl}+\mathrm{HO}_{2}$ & $\rightarrow$ & $\mathrm{HCl}+\mathrm{O}_{2}$ & $\mathrm{CH}_{3} \mathrm{Br}+\mathrm{O}\left({ }^{1} \mathrm{D}\right)$ & $\rightarrow$ & $\mathrm{Br}+$ products \\
\hline $\mathrm{ClO}+\mathrm{OH}$ & $\rightarrow$ & $\mathrm{Cl}+\mathrm{HO}_{2}$ & $\mathrm{CH}_{3} \mathrm{Br}+\mathrm{OH}$ & $\rightarrow$ & $\mathrm{Br}+$ products \\
\hline
\end{tabular}


Table 4. List of heterogeneous reactions. The cloud types on which the reactions happen are indicated (STS = supercooled ternary solution, NAT $=$ nitric acid trihydrate).

\begin{tabular}{|c|c|c|c|c|c|}
\hline \multicolumn{3}{|l|}{ Reaction } & \multirow{2}{*}{$\frac{\text { STS }}{\mathrm{x}}$} & \multirow{2}{*}{$\frac{\text { NAT }}{x}$} & \multirow{2}{*}{$\frac{\text { Ice }}{\mathrm{x}}$} \\
\hline $\mathrm{ClONO}_{2}+\mathrm{H}_{2} \mathrm{O}$ & $\rightarrow$ & $\mathrm{HOCl}+\mathrm{HNO}_{3}$ & & & \\
\hline $\mathrm{ClONO}_{2}+\mathrm{HCl}$ & $\rightarrow$ & $\mathrm{Cl}_{2}+\mathrm{HNO}_{3}$ & $\mathrm{x}$ & $\mathrm{x}$ & $\mathrm{x}$ \\
\hline $\mathrm{N}_{2} \mathrm{O}_{5}+\mathrm{H}_{2} \mathrm{O}$ & $\rightarrow$ & $\mathrm{HNO}_{3}+\mathrm{HNO}_{3}$ & $\mathrm{x}$ & $\mathrm{x}$ & $\mathrm{x}$ \\
\hline $\mathrm{N}_{2} \mathrm{O}_{5}+\mathrm{HCl}$ & $\rightarrow$ & $\mathrm{ClNO}_{2}+\mathrm{HNO}_{3}$ & & $\mathrm{x}$ & $\mathrm{x}$ \\
\hline $\mathrm{HOCl}+\mathrm{HCl}$ & $\rightarrow$ & $\mathrm{Cl}_{2}+\mathrm{H}_{2} \mathrm{O}$ & $\mathrm{x}$ & $\mathrm{x}$ & $\mathrm{x}$ \\
\hline $\mathrm{BrONO}_{2}+\mathrm{H}_{2} \mathrm{O}$ & $\rightarrow$ & $\mathrm{HOBr}+\mathrm{HNO}_{3}$ & $\mathrm{x}$ & & \\
\hline $\mathrm{HOBr}+\mathrm{HCl}$ & $\rightarrow$ & $\mathrm{BrCl}+\mathrm{H}_{2} \mathrm{O}$ & $\mathrm{x}$ & & \\
\hline
\end{tabular}

to NAT clouds. Surface area densities are calculated from the available $\mathrm{H}_{2} \mathrm{O}$ by assuming a particle number density of $0.01 \mathrm{~cm}^{-3}$ and a uniform particle radius. The fractions of $\mathrm{HNO}_{3}, \mathrm{H}_{2} \mathrm{O}$ and $\mathrm{HCl}$ contained in the cloud particles are not available for gas phase reactions.

\subsection{Lagrangian denitrification}

The model contains a Lagrangian denitrification module based on the DLAPSE model (Carslaw et al., 2002), which is implemented in the ATLAS model in a way similar to Grooß et al. (2005). Denitrification removes nitrogen by sedimenting PSC particles and can lead to additional ozone loss by impeding deactivation of chlorine into $\mathrm{ClONO}_{2}$. Denitrification in 1999/2000 was presumably caused by large NAT particles with radii above $10 \mu \mathrm{m}$ (Fahey et al., 2001). The scheme is based on the sedimentation of these NAT particles and not on the sedimentation of ice particles with co-condensed NAT or the sedimentation of smaller NAT particles, since both approaches would not be effective enough to explain the observed denitrification.

The denitrification module uses an independent second set of Lagrangian parcels for representing the particles, in addition to the air parcels that are used for transport and chemistry. Particles are created with a constant nucleation rate where NAT formation is possible and are allowed to sediment and change size in the following time steps until they eventually evaporate. These particles exist in the model in addition to the particles that are formed in the heterogenous chemistry module (these are usually smaller with typical radii of $1 \mu \mathrm{m}$ ). The coexistence of both particle modes is necessary to allow for a sufficient chlorine activation on the large surface area of the small mode and denitrification due to the Lagrangian particles at the same time. The small mode is assumed not to grow and sediment due to the depletion of $\mathrm{HNO}_{3}$ where these particles exist.

After every mixing step, new NAT particles are initialized at the positions of all air parcels of the model which are below the formation temperature of NAT (the procedure is somewhat different from Grooß et al. (2005), which uses more particles). Any of these particles is representative for a much larger number of real NAT particles, since the number of simulated particles needs to stay at a manageable level. This is considered by a scaling factor if interaction with the background nitric acid field is done. Particles are initialized with a uniform initial radius and are transported with the trajectory module of the model. Horizontal velocities are taken from the wind fields of the analysis, while the vertical velocities are the sum of the terminal fall velocities of the particles and the vertical velocities of the analysis. Terminal fall velocities $\mathrm{d} z / \mathrm{d} t$ of the particles are calculated from the particle radii $r$ by $\mathrm{d} z / \mathrm{d} t=C r^{2}$, where $C$ depends on the viscosity of air and the crystal mass density of NAT. Particle growth is calculated by $\mathrm{d} r / \mathrm{d} t=G / r$ where $G$ is a growth factor depending on the supersaturation of $\mathrm{HNO}_{3}$ with respect to NAT. If the calculated radius drops below zero, the particle evaporates. Details on the calculation of the fall velocities and the growth factor can be found in Appendix A.

For interaction with the background $\mathrm{HNO}_{3}$ field, the four air parcels of the model which form the enclosing tetrahedron of the particle are determined. At each of these four air parcels, it is assumed that a number density $n_{\text {NAT }}$ of NAT particles with the properties of the enclosed particle is present. If an air parcel is adjacent to several particles, the number densities are added. $n_{\text {NAT }}$ is the scale factor mentioned above and is a free parameter of the model which has to be tuned to observations. Note that the choice of air parcels is handled differently in Grooß et al. (2005). $\mathrm{HNO}_{3}$ in the gas phase is depleted if the NAT particle has grown in the last time step and set free if it decreased in size. A nucleation rate can be estimated from $n_{\text {NAT }}$ by multiplying it with four (for the four air parcels affected in each step) and dividing it by the mixing time step of the model.

The denitrification module is called after the chemistry module has calculated the evolution of the species for the length of the mixing time step (the chemistry module includes the equilibrium model of the heterogeneous chemistry module, which uses the total $\mathrm{HNO}_{3}$ not contained in the Lagrangian particles and partitions it into the gas phase and the solid phase for the small particles of the equilibrium model). The initial background $\mathrm{HNO}_{3}$ for the denitrification module is taken from the final total mixing ratio produced by the chemistry module (and not contained in the Lagrangian particles). Then the denitrification module is run for the length of the mixing time step (process splitting). Finally, $\mathrm{HNO}_{3}$ contained in the Lagrangian particles and the total background $\mathrm{HNO}_{3}$ is adjusted according to the results of the denitrification module.

If small particles are formed in the equilibrium model, they would leave exactly the saturation mixing ratio of $\mathrm{HNO}_{3}$ in the gas phase. That would impede the growth of the Lagrangian particles, since the growth factor $G$ would be zero in this case. The total and not the gas phase $\mathrm{HNO}_{3}$ is used as the available $\mathrm{HNO}_{3}$ in the denitrification model to avoid this behaviour. Under typical circumstances, when more $\mathrm{HNO}_{3}$ 
than the saturation mixing ratio is available, a part of the available background $\mathrm{HNO}_{3}$ is put into the Lagrangian particles in every mixing time step, while the gas phase $\mathrm{HNO}_{3}$ is constantly forced to the saturation mixing ratio, leaving less and less $\mathrm{HNO}_{3}$ for the small particles of the equilibrium model. That is, the combination of the equilibrium module and the particle module tends to transform particles from the small mode to the large mode with a time constant dependent on $G$ and $n_{\text {nat }}$.

This simplified scheme seems a reasonable compromise for two reasons: First, the exact mechanisms of the formation of the large and small NAT particle modes are still unknown. Second, the chlorine activation on the small mode and the denitrification due to the large mode are normally sufficiently fast (on the order of some days) for details of the exact timing not to matter for ozone loss and most of the chemistry.

\subsection{Freeze drying}

The only microphysical process apart from PSC formation and sedimentation considered in the model is freeze drying of water vapor at the tropical tropopause. It is assumed that all water vapor above the saturation mixing ratio is condensed and immediately removed from the air parcel by sedimentation.

\section{Model setup}

\subsection{Setup}

Model runs are driven by meteorological data from the ECMWF ERA Interim reanalysis (Simmons et al., 2006, 2007) on 60 model levels ( $6 \mathrm{~h}$ temporal resolution, $2^{\circ} \times 2^{\circ}$ horizontal resolution). Horizontal model resolution (as the initial mean separation of air parcels) is $150 \mathrm{~km}$. Vertical resolution is $1-2 \mathrm{~km}$ (in log-pressure altitude). The runs use the hybrid pressure-potential temperature coordinate of the model (Wohltmann and Rex, 2009), which is almost a pure potential temperature coordinate in the stratosphere. Heating rates (clear sky) from ERA Interim are used as the vertical velocity. The lower model boundary is at the hybrid level $350 \mathrm{~K}$ and the upper boundary at $1900 \mathrm{~K}$. Mixing strength by the Lyapunov exponent is set to $3 \mathrm{~d}^{-1}$ (optimal mixing, see Wohltmann and Rex, 2009) and the mixing time step to $12 \mathrm{~h}$. The run is started on 1 November 1999 and ends on 16 March 2000. Chemical species are initialized on 1 December. Chemical species at the lower and upper boundary are re-initialized every $12 \mathrm{~h}$, as described in Wohltmann and $\operatorname{Rex}(2009)$.

In addition to the chemical species, two tracers are initialized. A passive ozone tracer is initialized with the ozone values of 1 December, but no chemistry acts on the tracer in the following. The difference between the passive ozone tracer and the chemically active ozone is then a measure for chemical ozone depletion. In an equivalent way, a passive
$\mathrm{NO}_{\mathrm{y}}$ tracer is set up by adding up all nitrogen-containing species (except for $\mathrm{N}_{2} \mathrm{O}$ ). The difference between this tracer and $\mathrm{NO}_{\mathrm{y}}$ is then a measure for denitrification by sedimenting particles, since the number of $\mathrm{N}$ atoms in $\mathrm{NO}_{\mathrm{y}}$ cannot be changed by chemistry (except by reactions with $\mathrm{N}_{2} \mathrm{O}$ ).

A run with Lagrangian denitrification and a run without denitrification are started for comparison. $n_{\mathrm{NAT}}$ is set to $2.34 \times 10^{-5}$ particles per $\mathrm{cm}^{3}$, which corresponds to a nucleation rate of $7.8 \times 10^{-6}$ particles per $\mathrm{h}$ and $\mathrm{cm}^{3}$ (as in Grooß et al., 2005). No further sensitivity analyses are performed for this study, which focusses on the model description. The initial radius of the NAT particles is set to $0.1 \mu \mathrm{m}$.

A supersaturation of 5 is assumed necessary for the formation of the small NAT mode. The value is estimated from test runs by comparing measurements of $\mathrm{HNO}_{3}$ on flights of the ER-2 aircraft (see below) to the equilibrium values of $\mathrm{HNO}_{3}$ over NAT that should be present according to the measured temperatures and modeled water vapour.

\subsection{Measurements used for initialization and comparison}

A large number of measurements from many different instruments on different platforms is used to initialize the model in the following. Additionally, model results are compared to a similarly diverse collection of measurements. The following section gives an overview over the used data.

16 flights of the ER-2 high-altitude aircraft in altitudes of up to $20 \mathrm{~km}$ were performed during the campaign between 6 January and 16 March 2000. Flights between 20 January and 12 March started from Kiruna (Sweden) and probed the stratospheric polar vortex and surf zone, while the other flights were transfer and test flights. Table 5 shows the instruments onboard the ER-2 that are used for comparison and Table 6 shows a time table of the campaign.

ACATS-IV is a gas chromatograph measuring every 70140 s (Romashkin et al., 2001), while Argus and ALIAS are tunable diode laser instruments measuring with a high time resolution of $2 \mathrm{~s}$ (Loewenstein et al., 2002; Webster et al., 1994). These three instruments observe several long-lived species (CFCs, Halons, $\mathrm{N}_{2} \mathrm{O}, \mathrm{CH}_{4}$ ). The instrument measuring ozone is a dual-beam UV-absorption ozone photometer (Proffitt and McLaughlin, 1983). Water vapor is observed by a tunable diode laser instrument from JPL (May, 1998; Herman et al., 2002) and a fluorescence instrument from Harvard (Weinstock et al., 1994). The NOAA NOy instrument measures $\mathrm{NO}$ and $\mathrm{NO}_{\mathrm{y}}$ (that is, all reactive nitrogen reduced to $\mathrm{NO}$ on a catalysator) by chemiluminescence (Fahey et al., 1989, 2001). The instrument uses two different inlets with different sample characteristics with respect to aerosol particle size. Here, data of the rear inlet are used, which samples the gas phase and particles with a diameter of less than about $2 \mu \mathrm{m}$. Note that the instrument oversamples particles compared to the ambient air. $\mathrm{HNO}_{3}$ in the gas phase 
Table 5. Measurements used for initialization and comparison.

\begin{tabular}{|c|c|c|c|}
\hline Platform & Instrument & Species & Citation \\
\hline ER-2 & ACATS-IV & $\begin{array}{l}\mathrm{N}_{2} \mathrm{O}, \mathrm{CH}_{4}, \mathrm{CFC}-11, \mathrm{CFC}-12, \mathrm{CFC}-113, \\
\text { Halon-1211, } \mathrm{CH}_{3} \mathrm{CCl}_{3}, \mathrm{CCl}_{4}\end{array}$ & Romashkin et al. (2001) \\
\hline ER-2 & Argus & $\mathrm{N}_{2} \mathrm{O}, \mathrm{CH}_{4}$ & Loewenstein et al. (2002) \\
\hline ER-2 & ALIAS & $\mathrm{N}_{2} \mathrm{O}, \mathrm{CH}_{4}$ & Webster et al. (1994) \\
\hline ER-2 & Harvard $\mathrm{H} 2 \mathrm{O}$ & $\mathrm{H}_{2} \mathrm{O}$ & Weinstock et al. (1994) \\
\hline ER-2 & JPL JLH & $\mathrm{H}_{2} \mathrm{O}$ & $\begin{array}{l}\text { May (1998); } \\
\text { Herman et al. (2002) }\end{array}$ \\
\hline ER-2 & Harvard CO2 & $\mathrm{CO}_{2}$ & Boering et al. (1994) \\
\hline ER-2 & NOAA O3 & $\mathrm{O}_{3}$ & $\begin{array}{l}\text { Proffitt and McLaughlin (1983); } \\
\text { Richard et al. (2001) }\end{array}$ \\
\hline ER-2 & Harvard $\mathrm{ClONO} 2$ & $\mathrm{ClONO}_{2}, \mathrm{NO}_{2}, \mathrm{ClO}, \mathrm{Cl}_{2} \mathrm{O}_{2}$ & Stimpfle et al. $(1999,2004)$ \\
\hline ER-2 & NOAA NOy & $\mathrm{NO}_{\mathrm{y}}$ in gas and solid phase (see text), NO & Fahey et al. $(1989,2001)$ \\
\hline ER-2 & Cal. Tech. CIMS & gas phase $\mathrm{HNO}_{3}$ & $\begin{array}{l}\text { Dhaniyala et al. (2003) } \\
\text { McKinney et al. (2004) }\end{array}$ \\
\hline ER-2 & Harvard HOx & $\mathrm{OH}, \mathrm{HO}_{2}$ & Hanisco et al. (2002) \\
\hline OMS remote & JPL Mark IV & $\begin{array}{l}\mathrm{H}_{2} \mathrm{O}, \mathrm{O}_{3}, \mathrm{~N}_{2} \mathrm{O}, \mathrm{CO}, \mathrm{CH}_{4}, \mathrm{NO}, \mathrm{NO}_{2}, \mathrm{HNO}_{3}, \\
\mathrm{HCl}, \mathrm{ClO}, \mathrm{CH}_{2} \mathrm{O}, \mathrm{HOCl}, \mathrm{H}_{2} \mathrm{O}_{2}, \mathrm{~N}_{2} \mathrm{O}_{5}, \\
\mathrm{ClONO}_{2}, \mathrm{CH}_{3} \mathrm{Cl}, \mathrm{CFC}-11, \mathrm{CFC}-12 \\
\mathrm{CCl}_{4}, \mathrm{HCFC}-22, \mathrm{CFC}-113\end{array}$ & Toon $(1991)$ \\
\hline OMS remote & JPL SLS & $\mathrm{O}_{3}, \mathrm{HCl}, \mathrm{ClO}, \mathrm{N}_{2} \mathrm{O}, \mathrm{HNO}_{3}$ & Stachnik et al. (1992) \\
\hline OMS in-situ & NOAA LACE & CFC-11, CFC-12, Halon-1211, $\mathrm{N}_{2} \mathrm{O}, \mathrm{H}_{2}, \mathrm{CH}_{4}$ & Ray et al. (2002) \\
\hline Triple & Cryogenic WAS & $\mathrm{N}_{2} \mathrm{O}, \mathrm{CH}_{4}, \mathrm{Cl}_{\mathrm{y}}$ & Grooß et al. (2002) \\
\hline- & Ozone sondes & $\mathrm{O}_{3}$ & \\
\hline UARS & HALOE & $\mathrm{O}_{3}, \mathrm{CH}_{4}, \mathrm{H}_{2} \mathrm{O}, \mathrm{HCl}, \mathrm{NO}_{\mathrm{x}}$ & Grooß and Russell III (2005) \\
\hline SCISAT-1 & ACE FTS & $\mathrm{HNO}_{3}, \mathrm{CO}$ & $\begin{array}{l}\text { K. Walker, personal } \\
\text { communication, 2010; } \\
\text { Jones et al. (2010) }\end{array}$ \\
\hline
\end{tabular}

is measured by a chemical ionization mass spectrometer (CIMS) instrument (Dhaniyala et al., 2003; McKinney et al., 2004). The Harvard $\mathrm{ClONO}_{2}-\mathrm{NO}_{2}-\mathrm{ClO}-\mathrm{Cl}_{2} \mathrm{O}_{2}$ instrument (Stimpfle et al., 1999, 2004) is composed of a laser-induced resonance fluorescence instrument for measuring $\mathrm{NO}_{2}$ and a resonance fluorescence instrument for $\mathrm{ClO} . \mathrm{Cl}_{2} \mathrm{O}_{2}$ and $\mathrm{ClONO}_{2}$ are measured by thermal dissociation into $\mathrm{ClO}$. The Harvard $\mathrm{HO}_{\mathrm{x}}$ instrument measures $\mathrm{OH}$ by laser-induced fluorescence (Hanisco et al., 2002). $\mathrm{HO}_{2}$ is transformed to $\mathrm{OH}$ by chemical titration. $\mathrm{CO}_{2}$ is observed by infrared absorption (Boering et al., 1994).

Measurement uncertainties are typically a few percent for most instruments and are not shown in the subsequent plots. For some instruments the accuracies are not negligible and indicated by thin lines. This applies to the $\mathrm{ClO}(34 \%$ at $2 \sigma), \mathrm{Cl}_{2} \mathrm{O}_{2}(42 \%), \mathrm{ClONO}_{2}(42 \%)$ and $\mathrm{NO}_{2}(20 \%)$ measurements (Stimpfle et al., 2004) and the $\mathrm{OH}(26 \%)$ and $\mathrm{HO}_{2}$ (40\%) measurements (Hanisco et al., 2002). Measurements are typically made every few seconds for most instruments. Exceptions are ACATS-IV (70-140 s), CIMS (alternates between gas phase and solid measurements every $3 \mathrm{~min}$ ), $\mathrm{ClO}$ (35 s), $\mathrm{Cl}_{2} \mathrm{O}_{2}$ and $\mathrm{ClONO}_{2}$ (more than $35 \mathrm{~s}$ ).
Several balloon ascents are used for initialization and comparison. There were two balloon ascents of the OMS balloon with remote sensing measurements from the solar occultation Mark IV interferometer (Toon, 1991) and the Submillimeter Limb Sounder (SLS) instrument (Stachnik et al., 1992) on 3 December 1999 (used for initialization and comparison) and 15 March 2000 (used for comparison). Measured species can be found in Table 5. The OMS balloon was launched with an in-situ payload including the LACE instrument on 19 November 1999 (used for initialization) and 5 March 2000 (used for comparison). Cryogenic whole air sampler measurements on Triple balloon ascents on 27 January 2000 and 1 March are used for initialization (Grooß et al., 2002).

Measurements of the HALOE solar occultation instrument onboard the UARS satellite were used both for initialization and comparison. Measurements of the solar occultation ACE FTS interferometer instrument onboard the SCISAT-1 satellite were also used for initialization. Additionally, a number of ozone sondes from the stations Ny-Ålesund (high latitudes, Spitzbergen), Hohenpeissenberg (mid-latitudes, Germany) and Paramaribo (Suriname) and Samoa (tropics, SHADOZ data set, see Thompson et al., 2003) are used for comparison. 
Table 6. Time table of the measurements.

\begin{tabular}{ll}
\hline Date & Activity \\
\hline 19 Nov & OMS balloon in-situ \\
3 Dec & OMS balloon remote \\
6 Jan & ER-2 (pre-campaign) \\
9 Jan & ER-2 (pre-campaign) \\
11 Jan & ER-2 (pre-campaign) \\
14 Jan & ER-2 (transfer) \\
20 Jan & ER-2 (vortex) \\
23 Jan & ER-2 (vortex) \\
27 Jan & ER-2 (across vortex edge) \\
& Triple balloon \\
31 Jan & ER-2 (vortex) \\
2 Feb & ER-2 (vortex) \\
3 Feb & ER-2 (vortex) \\
26 Feb & ER-2 (vortex) \\
1 Mar & Triple balloon \\
5 Mar & ER-2, OMS balloon in-situ \\
7 Mar & ER-2 (vortex) \\
11 Mar & ER-2 (across vortex edge) \\
12 Mar & ER-2 (vortex) \\
15 Mar & OMS balloon remote \\
16 Mar & ER-2 (transfer) \\
\hline
\end{tabular}

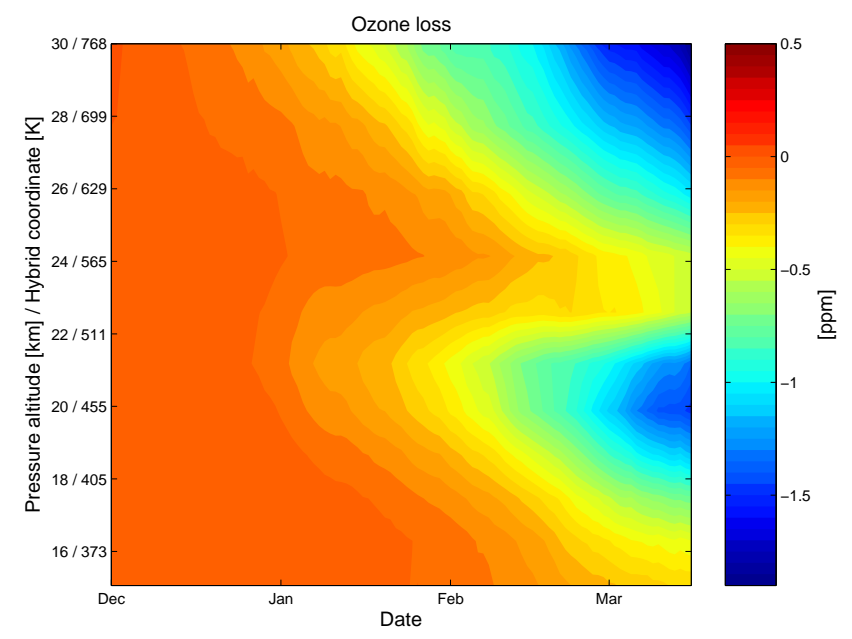

Fig. 2. Vortex-averaged ozone loss as function of model date and altitude. Difference between the passive ozone tracer and the modeled ozone averaged over all air parcels inside the inner vortex boundary according to the Nash criterion (Nash et al., 1996) and over several hybrid coordinate (i.e. potential temperature) intervals equivalent to the mixing depth of the model. Before 24 December 1999, the Nash criterion is not applicable and replaced by a constant value of $67^{\circ}$ equivalent latitude.

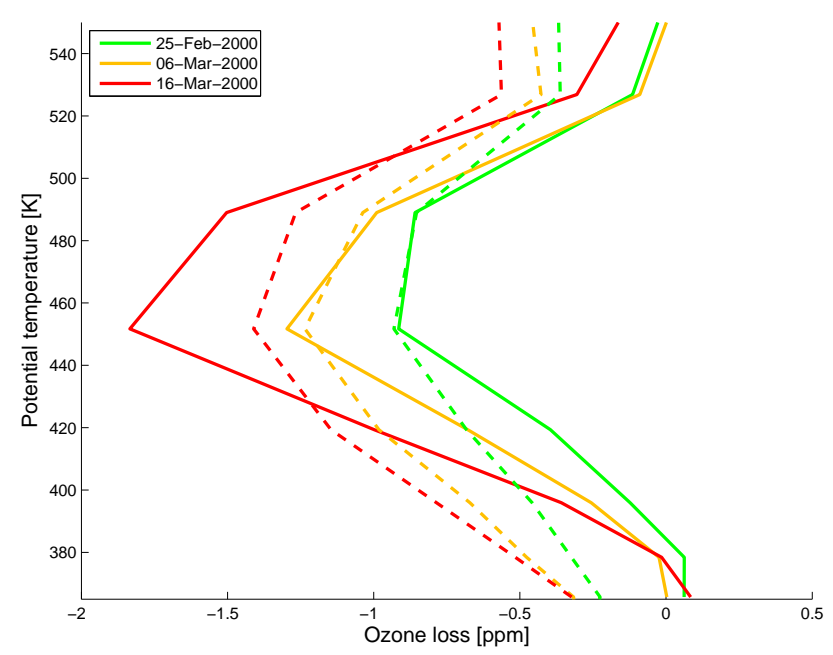

Fig. 3. Vortex-averaged ozone loss profiles for selected dates from measurements of ozone sondes treated by the vortex-average method (Rex et al., 2002, solid lines) and from the vortex-averaged results of the model (as in Fig. 2, but different vortex edge criterion, dashed lines). Results of the vortex-average method are convoluted to the altitude resolution of the model. The vortex edge criterion is identical to the one in Rex et al. (2002), both for model and measurements (40, 41, and 40 units of normalized PV, respectively).

\subsection{Initialization}

The long-lived species $\mathrm{H}_{2} \mathrm{O}, \mathrm{CH}_{4}, \mathrm{O}_{3}$ and $\mathrm{HCl}$ are initialized from monthly mean HALOE data of November and December 1999 as a function of equivalent latitude $\varphi_{\mathrm{E}}$ and pressure (Grooß and Russell III, 2005). All $\mathrm{NO}_{\mathrm{x}}$ from the monthly mean HALOE data set is put into NO. Since HALOE is not able to measure in high latitudes and darkness, the $\mathrm{CH}_{4}$ profiles inside the vortex $\left(\varphi_{\mathrm{E}}>64^{\circ} \mathrm{N}\right)$ are replaced by a single constant OMS in situ balloon profile from the LACE instrument determined on 19 November 1999 (Ray et al., 2002). $\mathrm{O}_{3}$ and $\mathrm{HCl}$ in the vortex are replaced in the same way by measurements of the Mark IV instrument (Toon, 1991) on the OMS remote sensing balloon flight on 3 December 1999. $\mathrm{N}_{2} \mathrm{O}$ is initialized from a $\mathrm{N}_{2} \mathrm{O}-\mathrm{CH}_{4}$ tracer-tracer relationship derived from ER-2 and Triple balloon data (Grooß et al., 2002). $\mathrm{HNO}_{3}$ and $\mathrm{CO}$ are taken from a climatology (20042009 mean) based on ACE FTS data as a function of pressure and equivalent latitude (K. Walker, personal communication, 2010; Jones et al., 2010). $\mathrm{HNO}_{3}$ inside the vortex is taken from the Mark IV measurement (see above). $\mathrm{ClONO}_{2}$ outside the vortex is initialized in two steps: first $\mathrm{Cl}_{\mathrm{y}}$ is calculated from $\mathrm{a} \mathrm{Cl}_{\mathrm{y}}-\mathrm{CH}_{4}$ relationship from ER-2 and Triple data (Grooß et al., 2002), where $\mathrm{Cl}_{\mathrm{y}}$ is deduced from the sum of the measured organic source gases. $\mathrm{ClONO}_{2}$ is then calculated as the difference between $\mathrm{HCl}$ and $\mathrm{Cl}_{\mathrm{y}}$. Negative values are set to zero. Maximum $\mathrm{Cl}_{\mathrm{y}}$ values obtained in this way are $3.4 \mathrm{ppb}$. $\mathrm{ClONO}_{2}$ inside the vortex is again taken from the Mark IV instrument. 


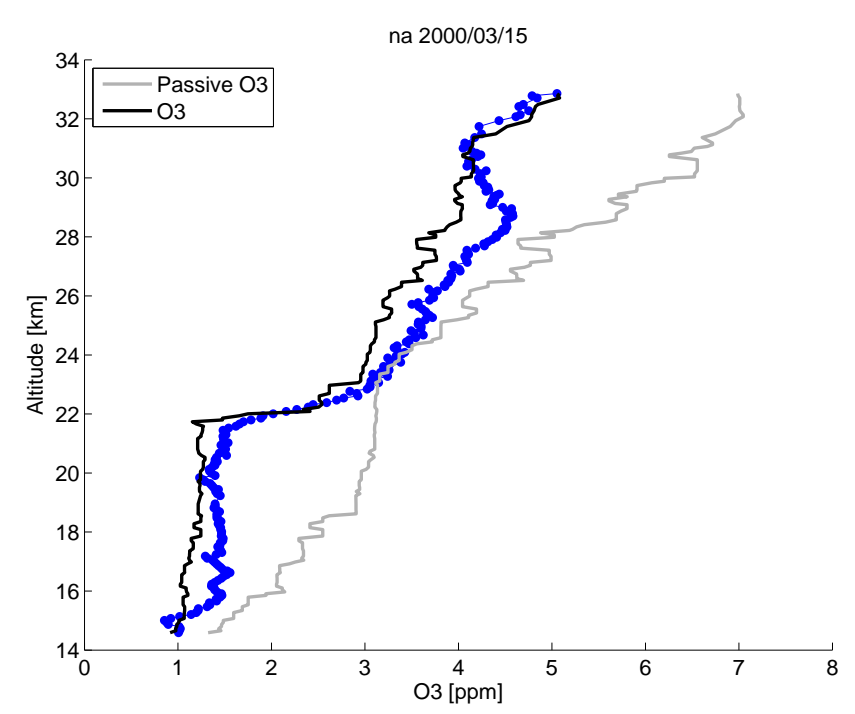

Fig. 4. Ozone sonde measurement from Ny-Ålesund, Spitzbergen on 15 March 2000 (blue dots) compared to modeled ozone values (black line). The grey line shows the passive ozone tracer to indicate the amount of ozone loss.

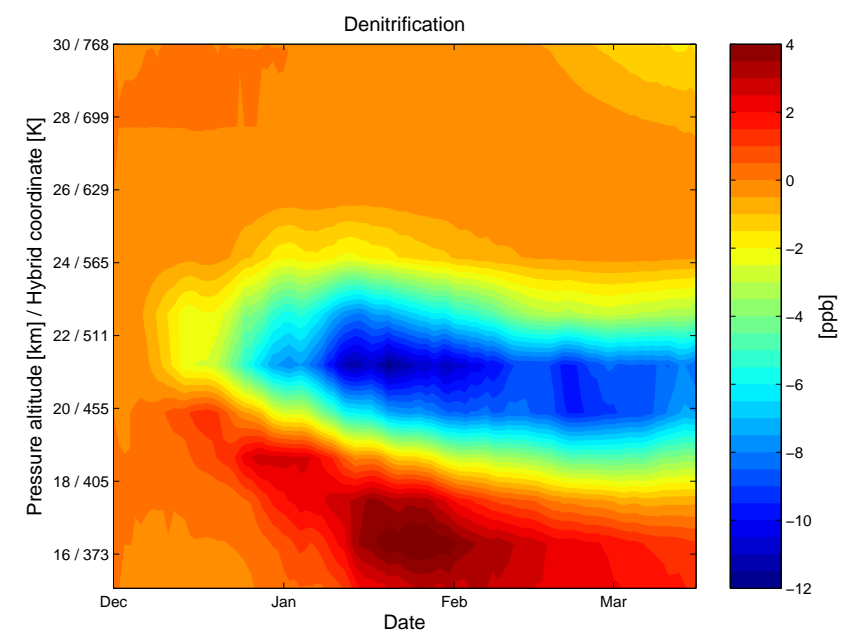

Fig. 5. Vortex-averaged denitrification as the difference of the passive $\mathrm{NO}_{\mathrm{y}}$ tracer and modeled $\mathrm{NO}_{\mathrm{y}}$, averaged as in Fig. 2.

$\mathrm{BrONO}_{2}$ is assumed to contain all $\mathrm{Br}_{\mathrm{y}}$, which is taken from a $\mathrm{Br}_{\mathrm{y}}-\mathrm{CH}_{4}$ relationship from ER-2 data in Grooß et al. (2002), with $\mathrm{Br}_{\mathrm{y}}$ again deduced from the measured organic source gases. The relationship does also contain a contribution from some short-lived source gases of 2-3 ppt. The relationship is only valid for methane values smaller than $1.64 \mathrm{ppm}$, for values between 1.64 and $1.8 \mathrm{ppm}, \mathrm{Br}_{\mathrm{y}}$ values are decreased from $6 \mathrm{ppt}$ to $0 \mathrm{ppt}$. The obtained $\mathrm{Br}_{\mathrm{y}}$ is scaled by a constant factor to give maximum $\mathrm{Br}_{\mathrm{y}}$ values of $19.9 \mathrm{ppt}$ to agree with Differential Optical Absorption Spectroscopy (DOAS) measurements of BrO (Dorf et al., 2008).
CFC-11, CFC-12 and Halon-1211 are initialized by $\mathrm{CH}_{4}$ tracer relationships derived from the LACE instrument on the OMS balloon flight on 19 November 1999 (Ray et al., 2002). Other CFCs and related species (CFC-113, $\mathrm{HCFC}-22, \mathrm{CCl}_{4}$, $\mathrm{CH}_{3} \mathrm{CCl}_{3}, \mathrm{CH}_{3} \mathrm{Cl}, \mathrm{CH}_{3} \mathrm{Br}$, Halon-1301) are initialized from their tropospheric mixing ratios and an age-of-air tracer. If the age of air is $t_{\mathrm{age}}$, the current date is $t$ and the tropospheric mixing ratio is $x_{\text {tropo }}$, the stratospheric mixing ratio is

$x_{\text {strato }}=\left(1-f\left(t_{\text {age }}\right)\right) x_{\text {tropo }}\left(t-t_{\text {age }}\right)$

The fractional release factor $f$ is the fraction of the source gas released into other substances. Age of air is taken from the $t_{\mathrm{age}}-\mathrm{N}_{2} \mathrm{O}$ relationships described in Woodbridge et al. (1995) and Andrews et al. (2001). Mixing ratios are calculated using both age-of-air relationships and averaging the results. Fractional release factors as a function of age of air are taken from Laube et al. (2010). Tropospheric mixing ratios are from input files of the CCMVal project (Eyring et al., 2008), which are based on WMO (2007). $\mathrm{CO}_{2}$ is initialized with the same method and $f=0$, tropospheric mixing ratios are taken from CCMVal based on IPCC (2001). All other species are set to zero.

\section{Model results}

In the next section, model results are compared to observations and results from other studies. The comparison includes the most important chemical families: oxygen species (ozone and ozone loss), nitrogen species $\left(\mathrm{NO}_{\mathrm{y}}, \mathrm{NO}_{\mathrm{x}}\right.$, denitrification), chlorine species $\left(\mathrm{ClO}_{\mathrm{x}}\right.$ and $\left.\mathrm{Cl}_{\mathrm{y}}\right)$, hydrogen species $\left(\mathrm{HO}_{\mathrm{x}}\right)$ and long-lived source gases. Only an exemplary subset of all comparisons conducted for this study is shown. A complete list of figures can be found in the Supplement, including the flight parameters (flight path, altitude, solar zenith angle and so on) for the balloons and ER-2 flights.

In the following, model results coincident to the measurements are obtained as follows: a short backward trajectory is calculated starting at the location and time of the measurement and ending at the time of the last model output before the measurement (model fields are saved every $12 \mathrm{~h}$ ). Typically, trajectories are started every $10 \mathrm{~s}$ along the flight path for the ER-2 measurements. Mixing ratios of all chemical species are interpolated from the neighboring air parcels of the model to the end location (i.e. earliest time) of the trajectory as initialization for the chemistry model. Now, the chemical box model is used to calculate the chemical evolution forward in time on the trajectory. The last computed value of each chemical species (coincident with the measurement date) is used as the model value to compare with. This procedure is needed since some of the shorter-lived species change substantially in the time period between model output and measurement date. 

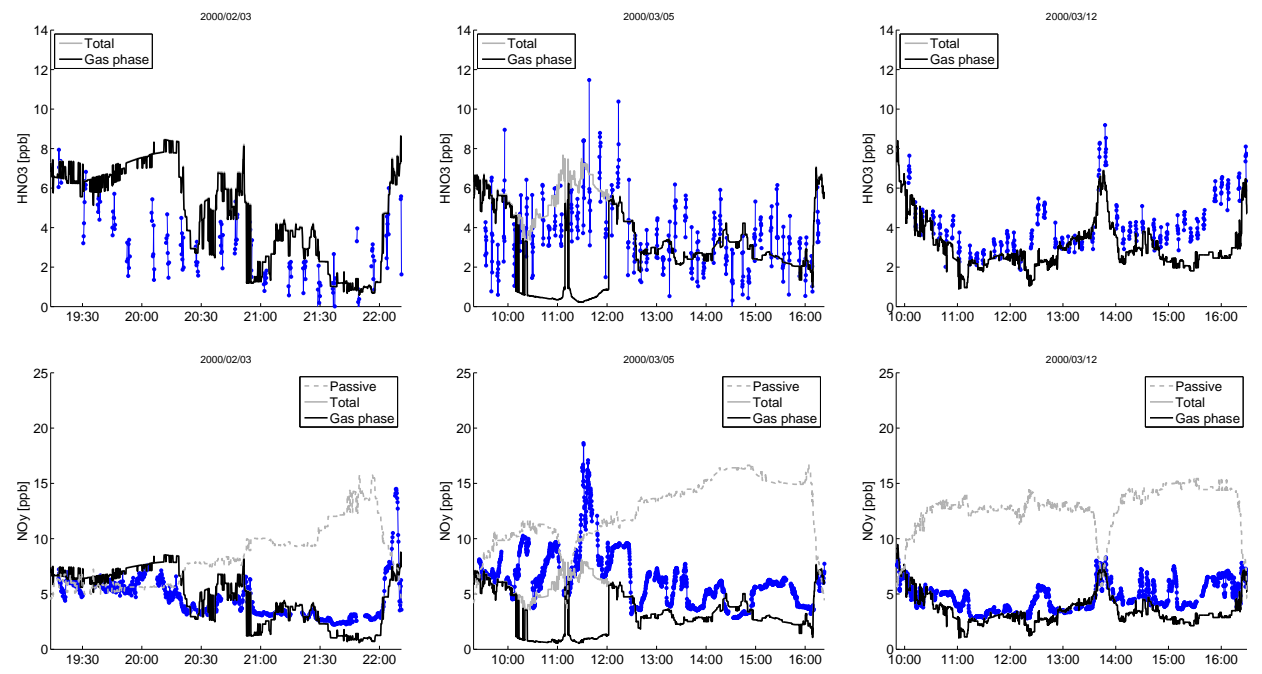

Fig. 6. $\mathrm{HNO}_{3}$ (top) and $\mathrm{NO}_{\mathrm{y}}$ (bottom) as a function of flight time (UTC) from measurements of selected ER-2 flights (3 February, 5 March, $12 \mathrm{March}$ ) (blue dots) compared to modeled values (lines). $\mathrm{NO}_{\mathrm{y}}$ measurements give the total (solid and gas phase, for details see text) values, $\mathrm{HNO}_{3}$ measurements show only the gas phase. The black line shows the model values for the gas phase, the grey line the total (solid not in the Lagrangian particles and gas phase) values and the dashed grey line the passive $\mathrm{NO}_{\mathrm{y}}$ tracer.

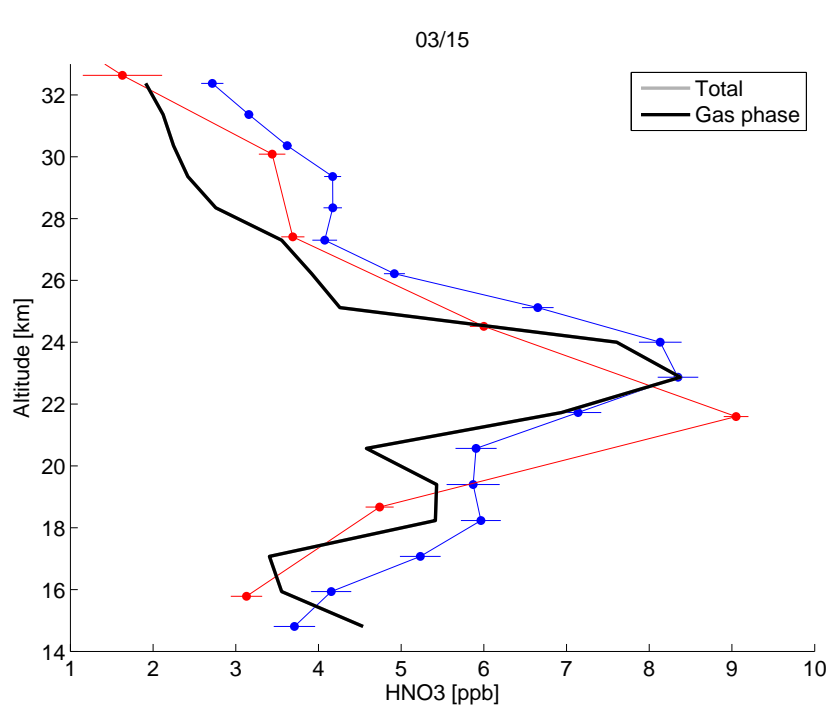

Fig. 7. $\mathrm{HNO}_{3}$ profile from the OMS balloon launch on 15 March 2000 measured by the Mark IV instrument (blue) and the SLS instrument (red). The black line shows the modeled profile. Note that Mark IV and SLS are remote sensing instruments viewing into opposite directions and that the mixing ratios of the species are interpolated to the Mark IV tangent points.

\subsection{Ozone loss}

Figure 2 shows the vortex-averaged ozone loss of the model for the run including denitrification. Ozone loss sets in about the beginning of January and develops a pronounced double- peak structure in altitude. While the lower peak is clearly due to ozone loss by halogens set free by heterogeneous reactions, the upper peak is probably due to $\mathrm{NO}_{\mathrm{x}}$ induced loss. The lower peak shows maximum loss values of $1.5 \mathrm{ppm}$ averaged over the layer from $433 \mathrm{~K}$ to $471 \mathrm{~K}$ in mid-March (approximately $50 \%$ ozone loss). The run without denitrification shows maximum loss values of $1.25 \mathrm{ppm}$, corresponding to about $17 \%$ additional loss $(0.25 \mathrm{ppm})$ by denitrification (not shown). Figure 3 shows the observed ozone loss deduced from ozone sondes by the vortex-average method and convoluted to the altitude resolution of the model (Rex et al., 2002) in comparison to the simulated ozone loss. The simulated ozone loss is generally in good agreement with the observations. Only for the latest date in mid-March, the sharp peak of $1.9 \mathrm{ppm}$ in the observations is smeared out somewhat in the simulation.

Comparison of the modeled ozone to individual ozone sondes or ozone measurements on the ER-2 flights generally shows good agreement (see Fig. 4 for a sounding from Ny-Ålesund, Spitzbergen, on 15 March and the Supplement for more examples). There is some discrepancy between the results of the vortex-average method from Rex et al. (2002) and the direct comparison to measurements: if anything, the comparison with individual sondes and ER-2 flights shows a slight overestimation of the loss by the model. This might be due to different heating rates and different initialization of the passive ozone profile in the model and in the vortexaverage method. In addition, passive ozone in the vortexaverage method is assumed not to be affected by mixing, while the passive ozone in the model can be changed by 

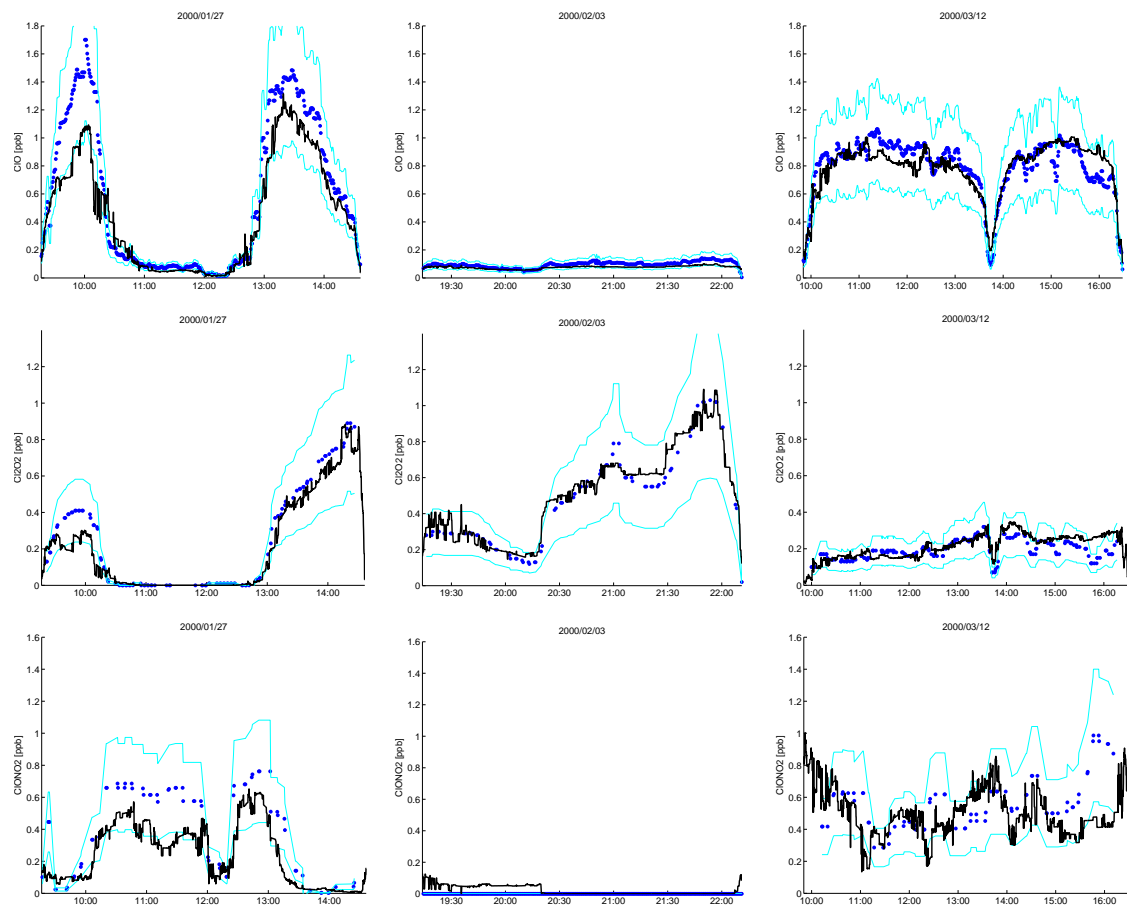

Fig. 8. $\mathrm{ClO}$ (top), $\mathrm{Cl}_{2} \mathrm{O}_{2}$ (middle) and $\mathrm{ClONO}_{2}$ (bottom) as a function of flight time (UTC) from measurements of selected ER-2 flights (27 January, 3 February, 12 March) (blue dots, cyan lines show $2 \sigma$ accuracy) compared to modeled values (black lines).
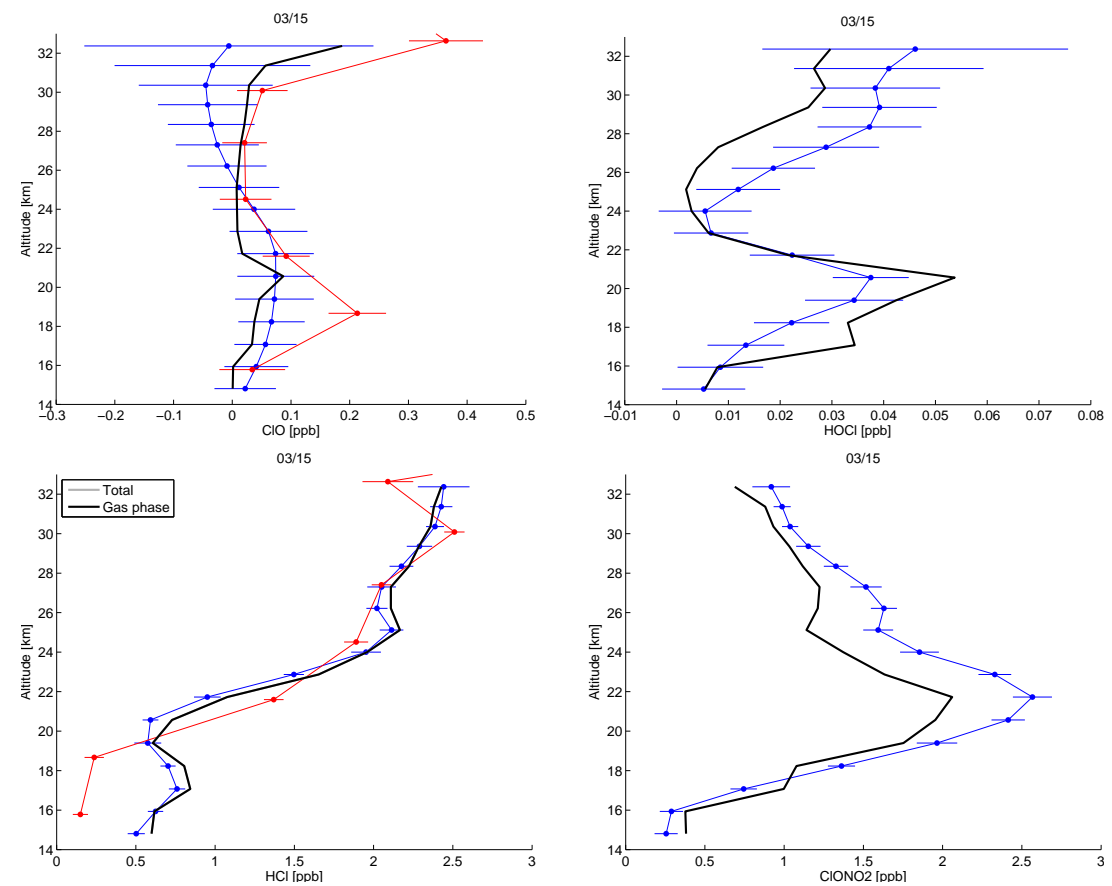

Fig. 9. $\mathrm{ClO}$ and its reservoirs $\mathrm{HOCl}, \mathrm{HCl}$ and $\mathrm{ClONO}_{2}$ from data of the $\mathrm{OMS}$ balloon launch on 15 March 2000. Measurements of the Mark IV instrument (blue, with error bars), the SLS instrument (red) and modeled values (black lines) are shown for comparison. Note that Mark IV and SLS are remote sensing instruments viewing into opposite directions and that the mixing ratios of the species are interpolated to the Mark IV tangent points. 

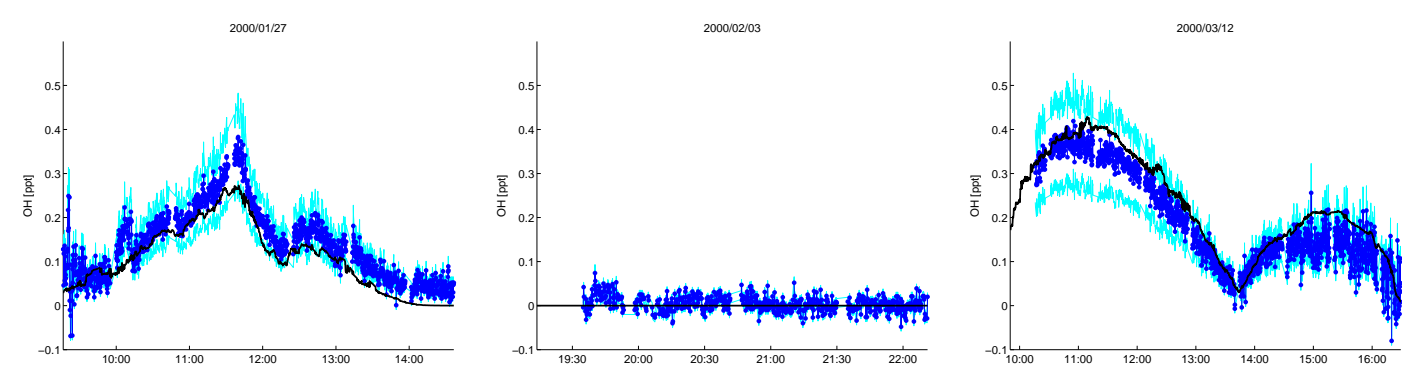

Fig. 10. $\mathrm{OH}$ as a function of flight time (UTC) from measurements of selected ER-2 flights (27 January, 3 February, and 12 March) (blue dots, cyan lines show $2 \sigma$ accuracy) compared to modeled values (black lines).
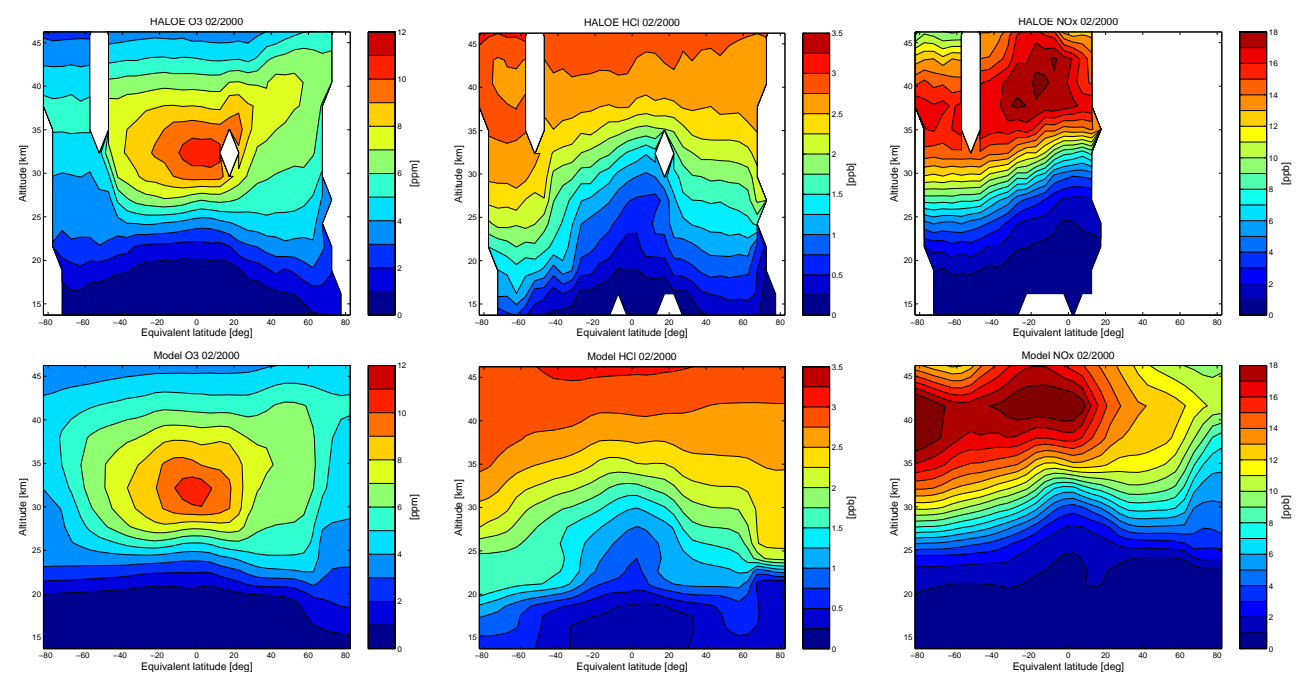

Fig. 11. Zonal and monthly mean mixing ratios for $\mathrm{O}_{3}, \mathrm{HCl}$ and $\mathrm{NO}_{\mathrm{x}}$ as a function of pressure altitude and equivalent latitude for February 2000. Top: HALOE measurements, bottom: modeled values.

mixing from outside the vortex (see Grooß et al., 2008). There is also some variation of ozone loss with equivalent latitude in the model results, with highest values of $1.7 \mathrm{ppm}$ ozone loss in the vortex core in mid-March (not shown). A direct estimate of ozone loss from the ER-2 flights by tracer correlations gives a loss of $1.8 \pm 0.3 \mathrm{ppm}$ (Richard et al., 2001). The general overestimation of ozone loss on both sides of the ozone loss peak could be due to a slightly too high vertical diffusivity in the model.

The agreement of simulated and observed ozone loss is very encouraging if compared with similar results from other models. The current version of the Eulerian model SLIMCAT captures the magnitude of the observations relatively well, but shows considerable differences in the shape of the profile (Chipperfield et al., 2005, their Fig. 2, note the different period 15 January to 25 March). The MIMOSA-CHIM model (Tripathi et al., 2006) shows an ozone loss of $1.9 \mathrm{ppm}$ at $475 \mathrm{~K}$ at the end of March (and about $1.75 \mathrm{ppm}$ in mid March). Magnitude and shape of the ozone loss profile (their
Fig. 1) and ER-2 comparisons (their Fig. 2) are in good agreement with our results.

In general, the ozone loss estimate from our model seems to be on the low side of the loss estimates from the other models presented here. The modeled additional ozone loss by denitrification of $17 \%(0.25 \mathrm{ppm})$ is in good agreement with Tripathi et al. (2006) (23\% and 0.2-0.4 ppm).

The vortex-average method is not applicable to the upper peak, but ozone sonde measurements inside the vortex show good agreement with the model results up to $35 \mathrm{~km}$. As an example, the sounding from $\mathrm{Ny}$-Ålesund on $15 \mathrm{March}$ is shown in Fig. 4.

\subsection{Denitrification and nitrogen species}

Figure 5 shows the modeled denitrification. Denitrification begins in early December and reaches peak values of $12 \mathrm{ppb}$ in January in the layer from 471-507 K. The denitrified layer typically extends over the levels from 433-594 K. Below the denitrified layer, renitrification is strongest (with maximum 
values of about $4.5 \mathrm{ppb}$ ) at altitudes of about $371-386 \mathrm{~K}$. The vertical extent and magnitude of denitrification in the model are in good agreement with the results of the denitrification study by Popp et al. (2001), which used ER-2 and Mark IV measurements (see also the direct comparison below). The denitrification scheme typically produces maximum particle radii of $10 \mu \mathrm{m}$ at altitudes between $16-18 \mathrm{~km}$, somewhat smaller than observed by Fahey et al. (2001).

Figure 6 shows selected ER-2 measurements of $\mathrm{NO}_{\mathrm{y}}$ and $\mathrm{HNO}_{3}$ and Fig. 7 shows $\mathrm{HNO}_{3}$ profiles from the Mark IV and SLS instruments on an OMS balloon ascent on 15 March 2000. The agreement between the modeled and observed $\mathrm{NO}_{\mathrm{y}}$ and $\mathrm{HNO}_{3}$ is quite reasonable, given the facts that there are considerable uncertainties in PSC formation and denitrification mechanisms and that the model was not tuned to the observations by sensitivity studies.

Note that the flight on 5 March shows no activity of polar stratospheric clouds, while the model formed PSCs. The flight on 5 March shows signs of supersaturation with respect to NAT. The assumed constant supersaturation of 5 in the model can only be an approximation to the complex formation processes of the clouds and it is difficult to find a value that matches all measurements. Some smaller discrepancies occur for the flights on 26 February, 5 March, and 7 March and species like gas phase $\mathrm{HNO}_{3}$ (underestimation), $\mathrm{ClONO}_{2}$ (underestimation) and $\mathrm{ClO}_{\mathrm{x}}$ (slight overestimation), see Supplement.

$\mathrm{NO}$ and $\mathrm{NO}_{2}$ are generally near zero inside the vortex in the model at the ER-2 flight altitude, in agreement with the measurements (see Supplement).

\section{3 $\mathrm{ClO}_{\mathrm{x}}$ and its reservoirs}

In general, the modeled evolution of both active chlorine $\left(\mathrm{ClO}, \mathrm{Cl}_{2} \mathrm{O}_{2}\right)$ and its reservoir gases $\left(\mathrm{HCl}, \mathrm{ClONO}_{2}, \mathrm{HOCl}\right)$ agrees with the measurements inside the error bars. However, there are some indications in the ER-2 and Mark IV data that $\mathrm{ClONO}_{2}$ might be a little bit too low.

Figure 8 shows measurements of $\mathrm{ClO}, \mathrm{Cl}_{2} \mathrm{O}_{2}$ and the reservoir species $\mathrm{ClONO}_{2}$ from selected ER-2 flights and Fig. 9 shows measurements of $\mathrm{ClO}, \mathrm{HOCl}, \mathrm{HCl}$ and $\mathrm{ClONO}_{2}$ of the Mark IV and the SLS instrument from the OMS balloon ascent on 15 March 2000. The flight on 27 January crossed the vortex edge, showing that the difference between vortex and surf zone is modeled well. The flight on 3 February shows measurements in darkness with high mixing ratios of the night-time reservoir $\mathrm{Cl}_{2} \mathrm{O}_{2}$ and low mixing ratios of $\mathrm{ClO}$, while the flight on 12 March took place in daylight and shows deactivation of chlorine into $\mathrm{ClONO}_{2}$. More comparisons can be found in the Supplement.

\section{$4.4 \mathrm{HO}_{\mathrm{x}}$}

Measured and modeled values of $\mathrm{HO}_{\mathrm{x}}$ agree inside the error bars of the measurements for most of the ER-2 flights.
Figure 10 shows comparisons of modeled $\mathrm{OH}$ values to measurements from selected ER-2 flights. $\mathrm{HO}_{2}$ shows a similarly good agreement (see Supplement).

\subsection{Long-lived species}

All major long-lived species $\left(\mathrm{N}_{2} \mathrm{O}, \mathrm{CH}_{4}, \mathrm{H}_{2} \mathrm{O}, \mathrm{CO}_{2}, \mathrm{CFC}\right.$ 11, CFC-12) are reproduced very well, both at all ER-2 flights and at all vertical profiles of the balloon flights (see Supplement). The agreement for $\mathrm{CH}_{4}$ and Halon-1211 has already been demonstrated in Wohltmann and Rex (2009). This gives confidence that the ERA Interim reanalysis driving the runs (and the formulation of the model) reproduce the general circulation in a sufficiently good quality. Differences of the chemical species between model and measurements are therefore likely due to problems in the chemistry module or measurement error.

\subsection{Agreement outside the polar vortex}

The data situation outside the vortex is somewhat worse than for polar measurements. Comparison of the modeled values with global zonal mean HALOE data, tropical ozone sondes and the precampaign ER-2 test flights show that the model is able to simulate the global large scale features of the chemical species correctly, albeit some of the species show larger differences outside the vortex due to the inferior initialization (see Supplement). As an example, Fig. 11 shows zonal and monthly mean mixing ratios of $\mathrm{O}_{3}, \mathrm{HCl}$ and $\mathrm{NO}_{\mathrm{x}}$ from HALOE measurements compared to model results for February 2000.

\section{Summary}

The model run with denitrification shows an excellent agreement with ER-2 aircraft, balloon and other measurements during the SOLVE/THESEO 2000 campaign. This is true both for long-lived tracers and species from all important chemical families, including ozone, chlorine species, nitrogen species and hydrogen species.

A maximum ozone loss of $1.5 \mathrm{ppm}$ or $50 \%$ averaged over $433-471 \mathrm{~K}$ and the polar vortex is simulated in mid-March, including an additional loss of $0.25 \mathrm{ppm}(17 \%)$ due to denitrification. The simulated ozone loss is in good agreement with observations.

The denitrification module produces a pronounced denitrification of up to $12 \mathrm{ppb}$ and particles of maximum sizes of $10 \mu \mathrm{m}$ (which are somewhat smaller particles than observed). Given the fact that no sensitivity studies with respect to denitrification and heterogeneous chemistry were conducted for this model description paper, the agreement with $\mathrm{HNO}_{3}$ and $\mathrm{NO}_{\mathrm{y}}$ measurements from the ER-2 is surprisingly good.

No major differences between model and observations are found in this study, indicating that Chemical Transport Models of the stratosphere could have reached a state of maturity. 
There are still considerable uncertainties remaining (e.g. in the formation mechanisms of polar stratospheric clouds or in denitrification mechanisms), but often the model results are relatively insensitive to them (e.g. to the exact mechanisms of chlorine activation, as long as it is sufficiently fast).

\section{Appendix A}

\section{Details of the denitrification scheme}

If not indicated otherwise, equations are taken from Carslaw et al. (2002). New particles are initialized at the positions of all model air parcels below $T_{\mathrm{NAT}}$ at every mixing time step with a uniform initial radius $r_{0}$. Particles are advected by the same wind field that acts on the air parcels. Additionally, the vertical velocity is modified by the terminal fall velocity of the particle, which for spherical particles in the Stokes regime is given by

$$
\frac{\mathrm{d} z}{\mathrm{~d} t}=\frac{2 g \rho_{\mathrm{NAT}} C_{\mathrm{C}} r^{2}}{9 \eta}
$$

where $g$ is acceleration due to gravity, $\rho_{\mathrm{NAT}}=1.62 \times$ $10^{3} \mathrm{~kg} \mathrm{~m}^{-3}$ is the mass density of NAT (of the solid, not per volume of air) (Mann et al., 2003),

$C_{\mathrm{C}}=1+\frac{\lambda}{r}\left(1.257+0.4 \exp \left(\frac{-1.1 r}{\lambda}\right)\right)$

is the Cunningham slip correction factor $(\lambda=$ $k_{\mathrm{B}} T /\left(4 \sqrt{2} \pi r_{\text {air }}^{2} p\right)$ mean free path of molecules, $r_{\text {air }} \approx 3 \times 10^{-10} \mathrm{~m}$ radius of air molecule, $k_{\mathrm{B}}$ the Boltzmann constant, $T$ temperature) and

$\eta=18.27 \times 10^{-6} \frac{T_{0}+C}{T+C}\left(\frac{T}{T_{0}}\right)^{3 / 2}$

is the viscosity of air in Pas $\left(C=120 \mathrm{~K}, T_{0}=291.15 \mathrm{~K}\right)$ (White, 1991). The growth of a NAT particle is given by

$$
\frac{\mathrm{d} r}{\mathrm{~d} t}=\frac{G}{r}
$$

where $G$ is a growth factor. Integration gives that the radius of the particle is changed by

$$
\Delta r=\sqrt{r^{2}+2 G \Delta t}-r
$$

in every time step $\Delta t$ of the trajectory model (every $30 \mathrm{~min}$ ). If $r$ gets negative, it is assumed that the particle evaporated and it is deleted. $G$ is given by

$G=\frac{D_{\mathrm{HNO}_{3}}^{*} m_{\mathrm{NAT}}}{\rho_{\mathrm{NAT}} k_{\mathrm{B}} T}\left(p_{\mathrm{HNO}_{3}}-p_{\mathrm{HNO}_{3}}^{\mathrm{NAT}_{3}}\right)$

where $D_{\mathrm{HNO}_{3}}^{*}$ is a modified diffusion coefficient of $\mathrm{HNO}_{3}$ in air, $m_{\mathrm{NAT}}=117 \times 1.66 \times 10^{-27} \mathrm{~kg}$ is the mass of a NAT molecule, $p_{\mathrm{HNO}_{3}}$ the partial pressure of $\mathrm{HNO}_{3}$ and $p_{\mathrm{HNO}_{3}}^{\mathrm{NAT}}$ the saturation pressure of $\mathrm{HNO}_{3}$ over NAT. $D_{\mathrm{HNO}}^{*}$ is a diffusion coefficient modified for non-continuum effects for small particles comparable to the mean free path,

$D_{\mathrm{HNO}_{3}}^{*}=\frac{D_{\mathrm{HNO}_{3}}}{1+4 D_{\mathrm{HNO}_{3}} /\left(\bar{c}_{\mathrm{HNO}_{3}} r\right)}$

where $\bar{c}_{\mathrm{HNO}_{3}}=\sqrt{8 k_{\mathrm{B}} T /\left(\pi m_{\left.\mathrm{HNO}_{3}\right)}\right.}$ is the mean molecular speed $\left(m_{\mathrm{HNO}_{3}}=63 \times 1.66 \times 10^{-27} \mathrm{~kg}\right.$ mass of $\mathrm{HNO}_{3}$ molecule) and

$D_{\mathrm{HNO}_{3}}=0.113\left(\frac{T}{T_{0}}\right)^{1.94}\left(\frac{p_{0}}{p}\right)$

the diffusion coefficient of $\mathrm{HNO}_{3}$ in air in $\mathrm{cm}^{2} \mathrm{~s}^{-1}\left(p_{0}=\right.$ $1013.25 \mathrm{hPa}, T_{0}=273 \mathrm{~K}$ ) (Wofsy et al., 1990).

The change of $\mathrm{HNO}_{3}$ mixing ratio in an air parcel if assuming a NAT particle number density $n_{\mathrm{NAT}}$ in that parcel is

$$
-\frac{4}{3} \pi\left((r+\Delta r)^{3}-r^{3}\right) \rho_{\mathrm{NAT}} \frac{n_{\mathrm{NAT}} k_{\mathrm{B}} T}{m_{\mathrm{NAT}} p}
$$

The $\mathrm{HNO}_{3}$ mixing ratio is changed according to this equation in the four air parcels of the model that form the enclosing tetrahedron of the NAT particle (obtained by triangulation) in every trajectory time step. $\mathrm{HNO}_{3}$ is either depleted or set free depending on the sign of the equation.

\section{Supplementary material related to \\ this article is available online at: http://www.geosci-model-dev.net/3/585/2010/ gmd-3-585-2010-supplement.pdf.}

Acknowledgements. We thank ECMWF for providing reanalysis data, R. Salawitch (U. Maryland) for providing the merged ER-2 data files, R. Stimpfle (Harvard U.) for providing ER-2 ClO, $\mathrm{ClONO}_{2}$ and $\mathrm{Cl}_{2} \mathrm{O}_{2}$ data, K. Perkins (Harvard U.) for providing $\mathrm{NO}_{2}$ data, D. Fahey (NOAA, National Oceanic and Atmospheric Administration) for providing ER-2 $\mathrm{NO}_{\mathrm{y}}$ and $\mathrm{NO}$ data, P. Wennberg (Cal. Tech.) for providing ER-2 CIMS $\mathrm{HNO}_{3}$ data, T. Hanisco (Harvard U.) for providing ER-2 $\mathrm{HO}_{\mathrm{x}}$ data, C. R. Webster (JPL, Jet Propulsion Laboratory, California Institute of Technology) for providing the ALIAS data, R. Herman (JPL) for providing ER-2 JLH $\mathrm{H}_{2} \mathrm{O}$ data, R. Spackman and E. Weinstock (Harvard U.) for providing ER-2 Harvard $\mathrm{H}_{2} \mathrm{O}$ data, S. Wofsy (Harvard U.) for providing ER-2 $\mathrm{CO}_{2}$ data, E. Richard (NOAA) for providing ER-2 $\mathrm{O}_{3}$ data, G. C. Toon (JPL) for providing Mark IV data, R. Stachnik (JPL) for providing SLS data, H. Claude (DWD) for the Hohenpeissenberg ozone sonde data, A. M. Thompson, H. Kelder, S. Oltmans and the SHADOZ programme for the Samoa and Paramaribo ozone sonde data, V. Eyring and the CCMVal activity for providing forcing data (greenhouse gases, CFCs, halons and surface area densities), J. W. Elkins (NOAA) for providing ACATS-IV and LACE data, H. Jost (NASA Ames Research Center) for providing the Argus data, K. Walker (U. Toronto) for providing ACE FTS data (The Atmospheric Chemistry Experiment (ACE), also known as SCISAT, is a Canadian-led mission mainly supported 
by the Canadian Space Agency), J.-U. Grooß and J. M. Russell III for providing HALOE data and ER-2 and Triple balloon tracer relationships. Work at AWI was supported by the EC DG research through the SHIVA project (SHIVA-226224-FP7-ENV-2008-1) and the SCOUT-O3 project.

Edited by: P. Jöckel

\section{References}

Andrews, A. E., Boering, K. A., Daube, B. C., Wofsy, S. C., Loewenstein, M., Jost, H., Podolske, J. R., Webster, C. R., Herman, R. L., Scott, D. C., Flesch, G. J., Moyer, E. J., Elkins, J. W., Dutton, G. S., Hurst, D. F., Moore, F. L., Ray, E. A., Romashkin, P. A., and Strahan, S. E.: Mean ages of stratospheric air derived from in situ observations of $\mathrm{CO}_{2}, \mathrm{CH}_{4}$, and $\mathrm{N}_{2} \mathrm{O}, \mathrm{J}$. Geophys. Res., 106, 32295-32314, 2001.

Boering, K. A., Daube, B. C., Wofsy, S. C., Loewenstein, M., Podolske, J. R., and Keim, E. R.: Tracer-tracer relationships and lower stratospheric dynamics: $\mathrm{CO}_{2}$ and $\mathrm{N}_{2} \mathrm{O}$ during SPADE, Geophys. Res. Lett., 21, 2567-2570, 1994.

Burkholder, J. B., Orlando, J. J., and Howard, C. J.: Ultraviolet absorption cross sections of chlorine oxide $\left(\mathrm{Cl}_{2} \mathrm{O}_{2}\right)$ between 210 and $410 \mathrm{~nm}$, J. Phys. Chem.-US, 94, 687-695, 1990.

Carslaw, K. S., Luo, B., and Peter, T.: An analytical expression for the composition of aqueous $\mathrm{HNO}_{3}-\mathrm{H}_{2} \mathrm{SO}_{4}$ stratospheric aerosols including gas phase removal of $\mathrm{HNO}_{3}$, Geophys. Res. Lett., 22, 1877-1880, 1995.

Carslaw, K. S., Kettleborough, J. A., Northway, M. J., Davies, S., Gao, R.-S., Fahey, D. W., Baumgardner, D. G., Chipperfield, M. P., and Kleinböhl, A.: A vortex-scale simulation of the growth and sedimentation of large nitric acid hydrate particles, J. Geophys. Res., 107, 8300, doi:10.1029/2001JD000467, 2002.

Chipperfield, M. P., Feng, W., and Rex, M.: Arctic ozone loss and climate sensitvity: updated three-dimensional model study, Geophys. Res. Lett., 32, 11813, doi:10.1029/2005GL022674, 2005.

Collins, W. J., Stevenson, D. S., Johnson, C. E., and Derwent, R. G.: Tropospheric ozone in a global-scale three-dimensional Lagrangian model and its response to $\mathrm{NO}_{\mathrm{x}}$ emission controls, J. Atmos. Chem., 26, 223-274, 1997.

Dhaniyala, S., Flagan, R. C., McKinney, K. A., and Wennberg, P. O.: Novel aerosol/gas inlet for aircraft-based measurements, Aerosol Sci. Tech., 37, 828-840, 2003.

Dorf, M., Butz, A., Camy-Peyret, C., Chipperfield, M. P., Kritten, L., and Pfeilsticker, K.: Bromine in the tropical troposphere and stratosphere as derived from balloon-borne $\mathrm{BrO}$ observations, Atmos. Chem. Phys., 8, 7265-7271, doi:10.5194/acp-8-72652008, 2008

Eyring, V., Chipperfield, M., Giorgetta, M. A., Kinnison, D. E., Manzini, E., Matthes, K., Newman, P. A., Pawson, S., Shepherd, T. G., and Waugh, D. W.: Overview of the new CCM$\mathrm{Val}$ reference and sensitivity simulations in support of upcoming ozone and climate assessments and the planned SPARC CCMVal report, SPARC News Lett., 30, 20-26, 2008.

Fahey, D. W., Kelly, K. K., Ferry, G. V., Poole, L. R., Wilson, J. C., Murphy, D. M., Loewenstein, M., and Chan, K. R.: In situ measurements of total reactive nitrogen, total water and aerosol in a polar stratospheric cloud in the Antarctic, J. Geophys. Res., 94, 11299-11315, 1989.
Fahey, D. W., Gao, R. S., Carslaw, K. S., Kettleborough, J., Popp, P. J., Northway, M. J., Holecek, J. C., Ciciora, S. C., McLaughlin, R. J., Thompson, T. L., Winkler, R. H., Baumgardner, D. G., Gandrud, B., Wennberg, P. O., Dhaniyala, S., McKinney, K., Peter, T., Salawitch, R. J., Bui, T. P., Elkins, J. W., Webster, C. R., Atlas, E. L., Jost, H., Wilson, J. C., Herman, R. L., Kleinböhl, A., and von König, M.: The detection of large $\mathrm{HNO}_{3}-$ containing particles in the winter Arctic stratosphere, Science, 291, 1026-1031, 2001.

Grooß, J.-U. and Russell III, James M.: Technical note: A stratospheric climatology for $\mathrm{O}_{3}, \mathrm{H}_{2} \mathrm{O}, \mathrm{CH}_{4}, \mathrm{NO}_{\mathrm{x}}, \mathrm{HCl}$ and $\mathrm{HF}$ derived from HALOE measurements, Atmos. Chem. Phys., 5, 2797-2807, doi:10.5194/acp-5-2797-2005, 2005.

Grooß, J.-U., Günther, G., Konopka, P., Müller, R., McKenna, D. S., Stroh, F., Vogel, B., Engel, A., Müller, M., Hoppel, K., Bevilacqua, R., Richard, E., Webster, C. R., Elkins, J. W., Hurst, D. F., Romashkin, P. A., and Baumgardner, D. G.: Simulation of ozone depletion in spring 2000 with the Chemical Lagrangian Model of the Stratosphere (CLaMS), J. Geophys. Res., 107, 8295, doi:10.1029/2001JD000456, 2002.

Grooß, J.-U., Günther, G., Müller, R., Konopka, P., Bausch, S., Schlager, H., Voigt, C., Volk, C. M., and Toon, G. C.: Simulation of denitrification and ozone loss for the Arctic winter 2002/2003, Atmos. Chem. Phys., 5, 1437-1448, doi:10.5194/acp-5-14372005, 2005.

Grooß, J.-U., Müller, R., Konopka, P., Steinhorst, H.-M., Engel, A., Möbius, T., and Volk, C. M.: The impact of transport across the polar vortex edge on Match ozone loss estimates, Atmos. Chem. Phys., 8, 565-578, doi:10.5194/acp-8-565-2008, 2008.

Hanisco, T. F., Smith, J. B., Stimpfle, R. M., Wilmouth, D. M., Anderson, J. G., Richard, E. C., and Bui, T. P.: In situ observations of $\mathrm{HO}_{2}$ and $\mathrm{OH}$ obtained on the NASA ER-2 in the highClO conditions of the 1999/2000 Arctic polar vortex, J. Geophys. Res., 107, 8283, doi:10.1029/2001JD001024, 2002.

Hanson, D. and Mauersberger, K.: Laboratory studies of the nitric acid trihydrate: Implications for the south polar stratosphere, Geophys. Res. Lett., 15, 855-858, 1988.

Herman, R. L., Drdla, K., Spackman, J. R., Hurst, D. F., Popp, P. J., Webster, C. R., Rosmashkin, P. A., Elkins, J. W., Weinstock, E. M., Gandrud, B. W., Toon, G. C., Schoeberl, M. R., Jost, H., Atlas, E. L., and Bui, T. P.: Hydration, dehydration, and the total hydrogen budget of the 1999/2000 winter Arctic stratosphere, J. Geophys. Res., 107, 8320, doi:10.1029/2001JD001257, 2002.

IPCC: Climate Change 2001: The scientific basis. Contribution of working group I to the third assessment report of the Intergovernmental Panel on Climate Change, Cambridge University Press, Cambridge, UK and New York, NY, USA, 2001.

Jones, A., Walker, K. A., Jin, J., Taylor, J. R., Boone, C. D., Bernath, P. F., Manney, G. L., McLeod, S., and Hughes, R.: A description of the ACE-FTS global climatological datasets, in preparation, 2010.

Konopka, P., Steinhorst, H.-M., Grooß, J.-U., Günther, G., Müller, R., Elkins, J. W., Jost, H.-J., Richard, E., Schmidt, U., Toon, G., and McKenna, D. S.: Mixing and ozone loss in the 1999-2000 Arctic vortex: simulations with the three-dimensional Chemical Lagrangian Model of the Stratosphere (CLaMS), J. Geophys. Res., 109, D02315, doi:10.1029/2003JD003792, 2004. 
Konopka, P., Günther, G., Müller, R., dos Santos, F. H. S., Schiller, C., Ravegnani, F., Ulanovsky, A., Schlager, H., Volk, C. M., Viciani, S., Pan, L. L., McKenna, D.-S., and Riese, M.: Contribution of mixing to upward transport across the tropical tropopause layer (TTL), Atmos. Chem. Phys., 7, 3285-3308, doi:10.5194/acp-7-3285-2007, 2007.

Krämer, M., Müller, R., Bovensmann, H., Burrows, J., Brinkmann, J., Röth, E. P., Grooß, J.-U., Müller, R., Woyke, T., Ruhnke, R., Günther, G., Hendricks, J., Lippert, E., Carslaw, K. S., Peter, T., Zieger, A., Brühl, C., Steil, B., Lehmann, R., and McKenna, D. S.: Intercomparison of stratospheric chemistry models under polar vortex conditions, J. Atmos. Chem., 45, 51-77, 2003.

Laube, J. C., Engel, A., Bönisch, H., Möbius, T., Sturges, W. T., Braß, M., and Röckmann, T.: Fractional release factors of long-lived halogenated organic compounds in the tropical stratosphere, Atmos. Chem. Phys., 10, 1093-1103, doi:10.5194/acp10-1093-2010, 2010.

Lehmann, R.: An algorithm for the determination of all significant pathways in chemical reaction systems, J. Atmos. Chem., 47, 45-78, 2004.

Loewenstein, M., Jost, H., Grose, J., Eilers, J., Lynch, D., Jensen, S., and Marmie, J.: Argus: a new instrument for the measurement of the stratospheric dynamical tracers, $\mathrm{N}_{2} \mathrm{O}$ and $\mathrm{CH}_{4}$, Spectrochim. Acta A, 58, 2329-2345, 2002.

Madronich, S. and Flocke, S.: The role of solar radiation in atmospheric chemistry, in: Handbook of Environmental Chemistry, edited by: Boule, P., Springer-Verlag, Heidelberg, 1-26, 1999.

Mann, G.W., Davies, S., Carslaw, K. S., and Chipperfield, M. P.: Factors controlling Arctic denitrification in cold winters of the 1990s, Atmos. Chem. Phys., 3, 403-416, doi:10.5194/acp-3403-2003, 2003.

Marti, J. and Mauersberger, K.: A survey and new measurements of ice vapor pressure at temperatures between 170 and $250 \mathrm{~K}$, Geophys. Res. Lett., 20, 363-366, 1993.

May, R. D.: Open-path, near-infrared tunable diode laser spectrometer for atmospheric measurements of $\mathrm{H}_{2} \mathrm{O}$, J. Geophys. Res., 103, 19161-19172, 1998.

McKenna, D. S., Grooß, J.-U., Günther, G., Konopka, P., and Müller, R.: A new Chemical Lagrangian Model of the Stratosphere (CLaMS) 2. Formulation of chemistry scheme and initialization, J. Geophys. Res., 107, 4256, doi:10.1029/2000JD000113, 2002.

McKinney, K. A., Wennberg, P. O., Dhaniyala, S., Fahey, D. W., Northway, M. J., Künzi, K. F., Kleinböhl, A., Sinnhuber, M., Küllmann, H., Bremer, H., Mahoney, M. J., and Bui, T. P.: Trajectory studies of large $\mathrm{HNO}_{3}$-containing PSC particles in the Arctic: evidence for the role of NAT, Geophys. Res. Lett., 31, L05110, doi:10.1029/2003GL018430, 2004.

Nash, E. R., Newman, P. A., Rosenfield, J. E., and Schoeberl, M. R.: An objective determination of the polar vortex using Ertel's potential vorticity, J. Geophys. Res., 101, 9471-9478, 1996.

Newman, P., Harris, N. R. P., Adriani, A., Amanatidis, G. T., Anderson, J. G., Braathen, G. O., Brune, W. H., Carslaw, K. S., Craig, M. S., DeCola, P. L., Guirlet, M., Hipskind, R. S., Kurylo, M. J., Küllmann, H., Larsen, N., Mégie, G. J., Pommereau, J.-P., Poole, L. R., Schoeberl, M. R., Stroh, F., Toon, O. B., Trepte, C. R., and Roozendael, M. V.: An overview of the SOLVE-THESEO 2000 campaign, J. Geophys. Res., 107,
8259, doi:10.1029/2001JD001303, 2002.

Popp, P. J., Northway, M. J., Holecek, J. C., Gao, R. S., Fahey, D. W., Elkins, J. W., Hurst, D. F., Romashkin, P. A., Toon, G. C., Sen, B., Schauffler, S. M., Salawitch, R. J., Webster, C. R., Herman, R. L., Jost, H., Bui, T. P., Newman, P. A., and Lait, L. R.: Severe and extensive denitrification in the 1999-2000 Arctic winter stratosphere, Geophys. Res. Lett., 28, 2875-2878, 2001.

Proffitt, M. H. and McLaughlin, R. J.: Fast-response dual-beam UVabsorption ozone photometer suitable for use on stratospheric balloons, Rev. Sci. Instrum., 54, 1719-1728, 1983.

Ray, E. A., Moore, F. L., Elkins, J. W., Hurst, D. F., Romashkin, P. A., Dutton, G. S., and Fahey, D. W.: Descent and mixing in the 1999-2000 northern polar vortex inferred from in situ tracer measurements, J. Geophys. Res., 107, 8285, doi:10.1029/2001JD000961, 2002.

Reithmeier, C. and Sausen, R.: ATTILA: atmospheric tracer transport in a Lagrangian model, Tellus B, 54, 278-299, 2002.

Rex, M., Salawitch, R. J., Harris, N. R. P., von der Gathen, P., Braathen, G. O., Schulz, A., Deckelmann, H., Chipperfield, M., Sinnhuber, B.-M., Reimer, E., Alfier, R., Bevilacqua, R., Hoppel, K., Fromm, M., Lumpe, J., Küllmann, H., Kleinböhl, A., Bremer, H., von König, M., Künzi, K., Toohey, D., Vömel, H., Richard, E., Aikin, K., Jost, H., Greenblatt, J. B., Loewenstein, M., Podolske, J. R., Webster, C. R., Flesch, G. J., Scott, D. C., Herman, R. L., Elkins, J. W., Ray, E. A., Moore, F. L., Hurst, D. F., Romashkin, P., Toon, G. C., Sen, B., Margitan, J. J., Wennberg, P., Neuber, R., Allart, M., Bojkov, B. R., Claude, H., Davies, J., de Backer, H., Dier, H., Dorokhov, V., Fast, H., Kondo, Y., Kyrö, E., Litynska, Z., Mikkelsen, I. S., Molyneux, M. J., Moran, E., Nagai, T., Nakane, H., Parrondo, C., Ravegnani, F., Skrivankova, P., Viatte, P., and Yushkov, V.: Chemical depletion of Arctic ozone in winter 1999/2000, J. Geophys. Res., 107, 8276, doi:10.1029/2001JD000533, 2002.

Richard, E. C., Aikin, K. C., Andrews, A. E., Daube, Jr., B. C., Gerbig, C., Wofsy, S. C., Romashkin, P. A., Hurst, D. F., Ray, E. A., Moore, F. L., Elkins, J. W., Deshler, T., and Toon, G. C.: Severe chemical ozone loss inside the Arctic polar vortex during winter 1999-2000 inferred from in situ airborne measurements, Geophys. Res. Lett., 28, 2197-2200, 2001.

Romashkin, P. A., Hurst, D. F., Elkins, J. W., Dutton, G. S., Fahey, D. W., Dunn, R. E., Moore, F. L., Myers, R. C., and Hall, B. D.: In situ measurements of long-lived trace gases in the lower stratosphere by gas chromatography, J. Atmos. Oceanic Technol., 18, 1195-1204, 2001.

Sander, S. P., Friedl, R. R., Ravishankara, A. R., Golden, D. M., Kolb, C. E., Kurylo, M. J., Molina, M. J., Moortgat, G. K., Finlayson-Pitts, B. J., Wine, P. H., Huie, R. E., and Orkin, V. L.: Chemical kinetics and photochemical data for use in atmospheric studies, Evaluation Number 15, JPL Publication 06-2, Jet Propulsion Laboratory, California Institute of Technology, Pasadena, available at: http://jpldataeval.jpl.nasa.gov (last access: May 2010), 2006.

Sander, S. P., Friedl, R. R., Abatt, J., Barker, J. R., Burkholder, J. B., Golden, D. M., Kolb, C. E., Kurylo, M. J., Moortgat, G. K., Wine, P. H., Huie, R. E., and Orkin, V. L.: Chemical kinetics and photochemical data for use in atmospheric studies, Evaluation Number 16, JPL Publication 09-31, Jet Propulsion Laboratory, 
California Institute of Technology, Pasadena, available at: http: //jpldataeval.jpl.nasa.gov (last access: May 2010), 2009.

Sandu, A. and Sander, R.: Technical note: Simulating chemical systems in Fortran90 and Matlab with the Kinetic PreProcessor KPP-2.1, Atmos. Chem. Phys., 6, 187-195, doi:10.5194/acp-6187-2006, 2006.

Shampine, L. F. and Reichelt, M. W.: The MATLAB ODE Suite, SIAM J. Sci. Comput., 18, 1-22, 1997.

Simmons, A. J., Uppala, S. M., Dee, D., and Kobayashi, S.: ERAInterim: new ECMWF reanalysis products from 1989 onwards, ECMWF News Lett., 110, 25-35, 2006.

Simmons, A. J., Uppala, S. M., and Dee, D.: Update on ERAInterim, ECMWF News Lett., 111, 5, 2007.

Stachnik, R. A., Hardy, J. C., Tarsala, J. A., and Waters, J. W.: Submillimeterwave heterodyne measurements of stratospheric $\mathrm{ClO}$, $\mathrm{HCl}, \mathrm{O}_{3}$ and $\mathrm{HO}_{2}$ : first results, Geophys. Res. Lett., 19, 19311934, 1992.

Stimpfle, R. M., Cohen, R. C., Bonne, G. P., Voss, P. B., Perkins, K. K., Koch, L. C., Anderson, J. G., Salawitch, R. J., Lloyd, S. A., Gao, R. S., DelNegro, L. A., Keim, E. R., and Bui, T. P.: The coupling of $\mathrm{ClONO}_{2}, \mathrm{ClO}$, and $\mathrm{NO}_{2}$ in the lower stratosphere from in situ observations using the NASA ER-2 aircraft, J. Geophys. Res., 104, 26705-26714, 1999.

Stimpfle, R. M., Wilmouth, D. M., Salawitch, R. J., and Anderson, J. G.: First measurements of $\mathrm{ClOOCl}$ in the stratosphere: the coupling of $\mathrm{ClOOCl}$ and $\mathrm{ClO}$ in the Arctic polar vortex, J. Geophys. Res., 109, D03301, doi:10.1029/2003JD003811, 2004.

Thompson, A. M., Witte, J. C., McPeters, R. D., Oltmans, S. J., Schmidlin, F. J., Logan, J. A., Fujiwara, M., Kirchhoff, V. W. J. H., Posny, F., Coetzee, G. J. R., Hoegger, B., Kawakami, S., Ogawa, T., Johnson, B., Vömel, H., and Labow, G.: Southern Hemisphere Additional Ozonesondes (SHADOZ) 1998-2000 tropical ozone climatology 1. Comparison with Total Ozone Mapping Spectrometer (TOMS) and ground-based measurements, J. Geophys. Res., 108, 8238, doi:10.1029/2001JD000967, 2003.

Toon, G. C.: The JPL MklV interferometer, Opt. Photonics News, 2, 19-21, 1991.
Tripathi, O. P., Godin-Beekmann, S., Lefèvre, F., Marchand, M., Pazmiño, A., Hauchecorne, A., Goutail, F., Schlager, H., Volk, C. M., Johnson, B., König-Langlo, G., Balestri, S., Stroh, F., Bui, T. P., Jost, H. J., Deshler, T., and von der Gathen, P.: High resolution simulation of recent Arctic and Antarctic stratospheric chemical ozone loss compared to observations, J. Atmos. Chem., 55, 205-226, doi:10.1007/s10874-006-9028-8, 2006.

Webster, C. R., May, R. D., Trimble, C. A., Chave, R. G., and Kendall, J.: Aircraft (ER-2) laser infrared absorption spectrometer (ALIAS) for in-situ stratospheric measurements of $\mathrm{HCI}, \mathrm{N}_{2} \mathrm{O}$, $\mathrm{CH}_{4}, \mathrm{NO}_{2}$, and $\mathrm{HNO}_{3}$, Appl. Optics, 33, 454-472, 1994.

Weinstock, E. M., Hintsa, E. J., Dessler, A. E., Oliver, J. F., Hazen, N. L., Demusz, J. N., Allen, N. T., Lapson, L. B., and Anderson, J. G.: New fast response photofragment fluorescence hygrometer for use on the NASA ER-2 and the Perseus remotely piloted aircraft, Rev. Sci. Instrum., 65, 3544-3554, 1994.

White, F. M.: Viscous Fluid Flow, McGraw-Hill, New York, 1991.

WMO: World Meteorological Organization (WMO)/United Nations Environment Programme (UNEP), Scientific assessment of ozone depletion: 2006, Global Ozone Research and Monitoring Project - Report No. 50, 2007.

Wofsy, S. C., Gobbi, G. P., Salawitch, R. J., and McElroy, M. B.: Nucleation and growth of $\mathrm{HNO}_{3} \cdot 3 \mathrm{H}_{2} \mathrm{O}$ particles in the polar stratosphere, J. Atmos. Sci., 47, 2004-2012, 1990.

Wohltmann, I. and Rex, M.: The Lagrangian chemistry and transport model ATLAS: validation of advective transport and mixing, Geosci. Model Dev., 2, 153-173, doi:10.5194/gmd-2-153-2009, 2009.

Woodbridge, E. L., Elkins, J. W., Fahey, D. W., Heidt, L. E., Solomon, S., Baring, T. J., Gilpin, T. M., Pollock, W. H., Schauffler, S. M., Atlas, E. L., Loewenstein, M., Podolske, J. R., Webster, C. R., May, R. D., Gilligan, J. M., Montzka, S. A., Boering, K. A., and Salawitch, R. J.: Estimates of total organic and inorganic chlorine in the lower stratosphere from in situ and flask measurements during AASE II, J. Geophys. Res., 100, 30573064, 1995. 